\title{
COMO AS DECISÕES SÃO PRODUZIDAS? UMA PROPOSTA DE REFORMULAÇÃO DE UM PROBLEMA DE PESQUISA
}

\section{HOW ARE DECISIONS MADE? A PROPOSAL TO REFORMULATE A RESEARCH PROBLEM}

RESUMO: O presente artigo tem por objetivo estimular o debate acerca da reformulação do seguinte problema de pesquisa: "como os juízes decidem?". Apesar de existir um corpo qualificado de autores que investigam o referido problema, falta ainda a discussão dos atos que antecedem e fazem parte do processo de produção de uma decisão judicial. Neste sentido, foram utilizadas as entrevistas concedidas por ministros ao projeto História Oral do STF para demonstrar que, antes mesmo de uma decisão judicial ser produzida e, portanto, levada à sessão de julgamento, existem diversos momentos capazes de influenciar diretamente não apenas na convicção do magistrado, mas no direito que está sendo produzido. Sendo assim, a partir da leitura das entrevistas, da noção de backstage trazida por Goffman (1975) e da organização de momentos considerados fundamentais pelos magistrados, pretende-se destacar a necessidade em se abrir uma agenda de pesquisa para investigar problema diverso ao anteriormente mencionado, qual seja: "como as decisões são produzidas?".

Palavras-Chave: Decisões judiciais; Supremo Tribunal Federal; Bastidores.

ABSTRACT: This paper aims to stimulate the debate about the reformulation of the research problem: "how do the judges decide?". Although there is a authors who investigate this problem, there isn't discussion about the acts that precede and are part of the process of producing a judicial decision. In this sense, the interviews given by judges to the Supreme Court Brazilian Oral History Project were used to demonstrate

\footnotetext{
${ }^{1}$ Professor Adjunto de Direito na Universidade Federal de Ouro Preto. Doutor em Teoria do Estado e Direito Constitucional pela Pontifícia Universidade Católica do Rio de Janeiro (PUC-Rio). O autor agradece à CAPES pelo financiamento do projeto de pesquisa do qual este artigo é resultado E-mail: carlosvictor@oi.com.br.
} 
that, even before a judicial decision is produced, and arrive at the decision-making, there are several moments capable of influencing the conviction of the magistrate and the rights being produced. Thus, from the reading of the interviews, the notion of backstage by Goffman (1975), and the organization of moments considered fundamental by judges, it is intended to highlight the need to open a research agenda to investigate a problem different from what previously mentioned, which is: "how are decisions made?".

KEYWORDS: Judicial decisions; Federal Court Brazilian; Backstage.

\section{INTRODUÇÃO}

O presente artigo apresenta diálogo direto com pesquisa já realizada e publicada neste mesmo periódico sob o título "A colegialidade nos tribunais: quando uma ideologia vira dogma e o dogma um princípio" ${ }^{2}$, oportunidade em que reconstituo e discuto o conceito de "colegialidade" nos tribunais brasileiros. O referido artigo inaugura uma série de discussões a respeito do exercício da colegialidade pelos ministros do Supremo, que são mais bem enfrentadas em tese de doutorado cujo título é: "O exercício da colegialidade no Supremo Tribunal Federal: entre a construção social do discurso e as práticas judiciárias" ${ }^{3}$. Dando continuidade às investigações empíricas a respeito da existência e o consequente exercício da colegialidade, ao confrontar o modo como ministros do Supremo registram a sua passagem pelo tribunal nos vinte e cinco primeiros anos da Constituição Federal, foi possível perceber a construção de diferentes discursos que podem ser situados no bojo de uma discussão a que chamo: "Como as decisões são produzidas?". Na pesquisa apresentada no artigo mencionado acima é possível ressaltar dois diferentes momentos no exercício da colegialidade por magistrados: a discussão e a deliberação. Em um primeiro momento, sugere-se que o órgão colegiado se reúna com seus magistrados e discutam oralmente questões de fato e de direito (a depender do tribunal) para, somente depois, chegarem a um consenso e deliberarem, i. e., produzirem uma decisão judicial. Alguns autores dedicam estudos e pesquisas a fim de investigar este segundo momento, inserido no debate que tramita em torno da famosa pergunta "Como os juízes decidem?".

Virgílio Afonso da Silva (2013), Conrado Hübner Mendes (2013) e André Rufino do Vale (2015), por exemplo, motivados pelo mencionado problema de pesquisa, buscam de diferentes identificar deliberações dos tribunais constitucionais capazes de apontar o modo como os decisores podem manifestar seus posicionamentos perante as questões jurídicas que lhes são demandadas. Outros estudos, como o Supremo em

${ }_{2}$ Disponível em: <https://www.estudosinstitucionais.com/REI/issue/view/4/showToc>. Acesso em: 08 nov.2018.

3 Tese de Doutorado apresentada ao Departamento de Direito da Pontifícia Universidade Católica do Rio de Janeiro, em 2017. Disponível em: <https://www.maxwell.vrac.puc-rio.br/31963/31963.PDF>. Acesso em: 08 nov.2018. 
Números, da FGV; CNJ em Números; IDJus, do IDP, dentre outros, a partir de um sistema de cruzamentos de dados por meio das informações disponibilizadas pelo Supremo Tribunal Federal, buscam criar um possível prognóstico de decisões judiciais a fim de diminuir a imprevisibilidade acerca do posicionamento de ministros e, consequentemente, antecipar suas manifestações acerca de casos específicos.

Há ainda pesquisas que (i) buscam compreender a dinâmica decisória dos ministros a partir do estabelecimento de uma relação com a indicação dos ministros feita pelos Presidentes da República e a sua linha ideológica (PRADO; TURNER, 2009; ARGUELHES; MOLHANO, 2010); (ii) traçam diferentes perfis dos julgadores a partir das decisões que proferem baseados em um algoritmo (OLIVEIRA, 2012); (iii) analisam clivagens do comportamento judicial a partir “ $(a)$ das circunstâncias históricas particulares em que as jurisdições constitucionais são praticadas; $(b)$ do significado político dos discursos que elas produzem; e $(c)$ dos dissensos e consensos jurisdicionais que as constituem" (SILVA, 2016, p. 04); dentre outras. Em comum, os estudos acima enfocam direta ou indiretamente a deliberação como forma de instruir respostas ao problema de pesquisa por eles investigados. A presente pesquisa apresenta problema diverso: a partir do acesso a diferentes discursos proferidos por magistrados em relação à sua produção de decisões judiciais, foi possível identificar diferentes atores e momentos capazes de influenciar esse processo decisório. O que nos atenta a uma nova problemática de pesquisa capaz de anteceder, influenciar e até mesmo modificar a percepção das diferentes respostas à problema de pesquisa "Como os juízes decidem?"

"Como as decisões são produzidas?" é a proposta de reformulação do problema de pesquisa mencionado acima. E para apresentá-la, o texto a seguir fará um tratamento qualitativo não bibliográfico acerca do exercício da colegialidade pelos ministros do Supremo Tribunal Federal nas sessões de julgamento. Para dar início a esse tipo de abordagem, optou-se por proceder a uma análise das entrevistas concedidas por alguns ministros do Supremo ao Projeto História Oral do STF4, que teve por objetivo criar uma base de dados a partir da concessão de entrevistas de cada um dos ministros que passaram pelo Supremo Tribunal Federal nos vinte e cinco primeiros anos da Constituição Federal de 1988. Um dos principais objetivos desse projeto era permitir que cada um dos ministros que compuseram a Corte no período indicado pudesse dar contribuições, por meio do resgate em suas memórias, à construção de uma narrativa histórica e institucional acerca do Supremo Tribunal Federal nos vinte e cinco primeiros anos da Constituição. Com a concessão das entrevistas, os ministros contribuíram à elaboração de uma base de dados que está integralmente disponibilizada pelas organizadoras do projeto, permitindo o registro detalhado de fenômenos sócio-jurídicos fundamentais à compreensão da instituição judiciária objeto da pesquisa.

O objetivo dos dados disponibilizados pelo Projeto HOSTF é o de registrar a visão e compreensão de atores sociais diretamente envolvidos com o fenômeno investigado. A reconstrução da memória e o esforço em atribuir sentidos a determinados atos ou fatos sociais são representativos do empenho de cada um deles em registrar não

${ }^{4}$ Disponível em: <http://historiaoraldosupremo.fgv.br/sobre-o-projeto>. Acesso em 31 jul. 2018; e $<$ http://bibliotecadigital.fgv.br/dspace/handle/10438/13570>. Acesso em: 31 jul. 2018. 
apenas o que vivenciaram, mas principalmente em firmar posição sobre como desejam que os fatos supostamente vividos sejam enxergados pelo público alvo de seu discurso. Isto é, a história oral representa, sobretudo, o registro de um olhar dos atores sociais sobre fenômenos em que estejam direta ou indiretamente envolvidos.

A partir de agora, dedicarei algumas páginas a fim de reconstituir, de acordo com os depoimentos orais dos entrevistados, possíveis caminhos aos quais uma determinada demanda pode se utilizar para chegar à sessão de julgamento e ser discutida e deliberada. Para tanto, a exposição a seguir apresentará quatro diferentes momentos, aqui chamado de dimensões: a primeira chamada "Distribuição e gestão dos processos pelos ministros"; a segunda, "Construindo a relevância e controlando a imparcialidade"; em seguida, será a vez da denominada "Administrando conflitos na informalidade"; e, por fim, a que chamarei de "a gestão do processo pelo Presidente".

Cada uma das fases anteriormente citadas apresentará alguns temas que serão discutidos individualmente a partir de consulta às entrevistas, acrescidos da identificação de expressões sugeridas pelos próprios ministros, a que chamarei de "categorias narrativas", para sintetizar, rotular ou explicar fenômenos sócio-jurídicos. Assim, será dado início à identificação de diferentes percursos que uma demanda poderá seguir até chegar à sessão de julgamento, além de identificar elementos apontados pelos próprios ministros como responsáveis por influenciar também a discussão e deliberação em plenário.

Para melhor descrever todo o processo acima, nas páginas seguintes serão apresentadas: justificativas acerca da escolha de utilização das entrevistas concedidas pelos ministros ao Projeto História Oral do STF como fonte de acesso a algumas categorias narrativas; a metodologia utilizada, bem como a proposta de desenvolvimento do raciocínio que se deseja construir; a apresentação do contexto em que as categorias narrativas foram identificadas e as funções que são capazes de cumprir; e o mapeamento das categorias narrativas que fazem referência ao exercício da colegialidade, destacando a possibilidade de representarem parâmetros de organização do modus operandi de uma decisão judicial.

\section{Aspectos MetOdOLÓGICOS}

Inicialmente, é importante destacar que o universo de pesquisa dos capítulos a seguir se resumem à totalidade das entrevistas já publicadas e disponibilizadas ao público pelo Projeto História Oral do STF. As entrevistas abrangem um período de 1988 a 2013, conhecidos também como os primeiros vinte e cinco anos de vigência da Constituição Federal.

E apesar do acesso privilegiado à base de dados da pesquisa por ter integrado a equipe do projeto, devido ao uso do método técnica-fonte pelo HOSTF (ALBERTI, 2004), só foi possível utilizar a base de dados criados a partir dos depoimentos orais dos ministros entrevistados após a revisão feita por cada um deles nas transcrições de suas entrevistas e que tiveram, consequentemente, sua publicação autorizada. Por tais motivos, apesar de o projeto HOSTF ter como objetivo a entrevista dos vinte e oito ministros ainda vivos e que tiveram passagem pelo STF, apenas vinte e uma

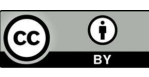


entrevistas (que representam a totalidade das que foram publicadas até o dia 31 de julho de 2018) foram efetivamente utilizadas na presente pesquisa.

A partir da leitura de tais entrevistas, foi feito um recorte que mais se aproximasse do objeto de estudo desta pesquisa: a identificação de atos ou fatos que apresentassem algum tipo de relação com as dinâmicas ocorridas nos órgãos colegiados capazes de mapear diferentes modos de produção de uma decisão judicial. Com a base de dados definida, para fins de atribuição de destaque aos trechos das entrevistas que faziam referência às dinâmicas ocorridas nas sessões de julgamento, procedeu-se a leitura na íntegra de cada umas das entrevistas.

Durante a leitura, foram identificados diversos trechos que faziam alusão às dinâmicas ocorridas nas sessões de julgamento, mas não apenas a elas. Foi percebido também que diversos ministros faziam referência a procedimentos que ocorriam fora das sessões de julgamento e que exerciam influência direta ou indireta sobre elas. Devido ao estabelecimento da relação entre eventos ocorridos fora das sessões de julgamento, mas com condições de exercer influência sobre elas, feitos pelos próprios ministros, optei por fazer menção também a esses momentos. Mas com o destaque de que os ministros pouco fazem referências às sessões de julgamento ocorridas na primeira ou segunda turmas, o que significa que os trechos selecionados nas entrevistas se relacionará direta ou indiretamente com as reuniões realizadas às portas abertas nas sessões plenárias.

E, com a leitura na íntegra de cada uma das entrevistas e a consequente separação de trechos que fizessem remissão aos momentos que antecedem a sessão de julgamento, demonstrando os diferentes modos de produção de uma decisão judicial, o passo seguinte foi o de proceder a um mapeamento de categorias narrativas utilizadas pelos próprios ministros em seus discursos para destacar algumas das dinâmicas que não poderiam deixar de ser observadas, sem qualquer preocupação em confirmar ou desmentir o construído pelo ministro do STF em entrevista concedida ao Projeto História Oral do STF - o que resultou nas chamadas "dimensões" que a seguir serão expostas. A expressão será comumente utilizada no presente trabalho por fazer referência a diferentes momentos descritos pelos ministros no exercício do colegiado, mas que não estimulam necessariamente a formação de um consenso entre eles. Isto é, de acordo com os relatos concedidos pelos ministros foi possível identificar vários elementos de um sistema capaz de dificultar o alcance a um consenso entre os ministros nos casos por eles apreciados no exercício do colegiado.

Assim, foi possível identificar temas em comum destacados por diferentes ministros e que ocuparam diferentes épocas no Supremo. Adotado o referido procedimento, bastou reler todos os trechos de entrevistas, desta vez agrupados por temas e fazendo referências a assuntos comuns ou conexos, para identificar categorias narrativas lançadas pelos ministros para sintetizar, rotular ou explicar fenômenos por eles descritos. O que poderá ser notado nas páginas seguintes, a partir da leitura dos tópicos destinados ao desenvolvimento das questões até aqui suscitadas. 


\section{PRIMEIRA DIMENSÃO: DISTRIBUIÇÃO E GESTÃO DOS PROCESSOS PELOS MINISTROS}

Após ser empossado como ministro do Supremo, o passo seguinte é assumir, ou melhor, herdar o gabinete de seu antecessor. E uma das maiores surpresas registradas pelos ministros entrevistados refere-se ao volume de processos e ritmo intenso de trabalho. E a medida a ser adotada não é outra senão proceder a organização da força de trabalho que dispõem para dar seguimento às atividades deixadas por seu antecessor. Para tanto, é preciso conhecer algumas das principais atividades desenvolvidas pelos ministros do Supremo. É preciso conhecer suas rotinas e cargas de trabalho, além de desenvolver técnicas eficazes de administração de tempo e gestão dos recursos humanos e da infraestrutura que dispõem para melhor desempenharem seus papéis de magistrados.

Isto é, para ser ministro, é preciso também conhecer o Supremo por dentro, algo que somente se torna possível após ser empossado. Sendo assim, nas próximas linhas serão demonstrados alguns passos ao que está sendo considerado como uma primeira dimensão do percurso de uma demanda à sessão de julgamento no plenário do Supremo: a fase de conhecimento do Supremo, o que inclui desde o choque em relação ao volume de processos que aguarda o ministro mais novo até o modo em que organizará a sua força de trabalho.

\section{Da emoção em ser empossado ao recebimento de uma "herança maldita": como lidar com o volume de processos?}

Ao ser empossado, alguns ministros do Supremo parecem não ter a dimensão exata da quantidade de trabalho que os aguardam em seus gabinetes. E, segundo ministros entrevistados, a carga de trabalho parece só aumentar com o passar dos anos (FONTAINHA; MAFEI, 2016, p. 110). Mas esta pode não ser a visão dos ministros recém-chegados ao Supremo ao conquistar uma vaga na corte que representa o mais alto órgão do Poder Judiciário brasileiro. Até assumir seu gabinete e conhecer seu novo ambiente de trabalho, o ministro recém-empossado pode ainda estar emocionalmente envolvido com o novo momento de sua trajetória jurídico-profissional. Ou seja, em um primeiro momento, a emoção pela "conquista" ou simplesmente pelo exercício do novo cargo pode ser representada como um dos atos que conduz o ministro recémchegado ao seu novo ambiente de trabalho (FONTAINHA; DE PAULA; NUÑEZ, 2015, p. 121).

Mas a satisfação em estar assumindo o cargo de ministro do Supremo pode ser rapidamente substituída pelo sentimento de angústia. Ao assumir seu gabinete, o ministro recém-chegado se depara com um alto volume de processos com que precisará lidar em toda a sua estadia no Supremo. O ministro Célio Borja, que ocupou o cargo no Supremo de 1986 a 1992, em sua entrevista afirma que, à sua época, o volume de processos já era razão de angústias de um ministro (FONTAINHA; DA SILVA; GUIMARÃES, 2015, p. 86-87). Apesar de a quantidade de processo no Supremo ser tema discutido a décadas, ministros recém-chegados ainda se surpreendem com o alto volume de processos que terão que gerir em seus gabinetes,

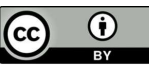

5 JOURNAL OF INSTITUTIONAL STUDIES 1 (2019)

Revista Estudos Institucionais, v. 5, n. 1, p. 171-216, jan./abr. 2019 
o que pode ser capaz de demonstrar que o volume de processos tanto já pode ser esperado pelos ministros quanto pode superar as expectativas do recém-chegado em relação ao trabalho a desenvolver na Corte.

A quantidade de processos com que um ministro recém-chegado se depara é, certamente, algo com que terá que lidar por todo o tempo em que ocupar o cargo de ministro. Por tais motivos, representa constante preocupação e incômodo entre eles. Nas entrevistas concedidas, todos os ministros demonstraram incômodo com o volume de processos que existe no Supremo. O que permitiu uma mobilização dos mais diversos setores (criação de tribunais, teses jurídicas, instrumentos e requisitos processuais, reformas legislativas, dentre outros) a fim de diminuir a carga de trabalho dos ministros e, consequentemente, melhorar a prestação jurisdicional.

O primeiro movimento foi iniciado pela proposta de modificação da estrutura do Poder Judiciário brasileiro, ao extinguir o Tribunal Federal de Recursos e criar o Superior Tribunal de Justiça, considerado um acerto pelo ministro Rafael Mayer, que ocupou o cargo de ministro do Supremo de 1978 a 1989. E ao ser perguntado a respeito da redefinição de competências do Supremo a partir da criação de um novo órgão jurisdicional, o ministro Rafael Mayer considera essa como uma medida acertada ao alívio da sobrecarga de processos característico do Supremo (FONTAINHA; MATTOS; NUÑEZ, 2015, p. 67-68).

A medida implementada pela Constituição Federal de 1988 parece ter contribuído com a redefinição de competências do Supremo e, consequentemente, ter concentrado a discussão de questões constitucionais no tribunal. Mas, conforme demonstrado anteriormente, apesar da medida, a carga de trabalho tende a crescer e se intensificar com o passar dos anos. Outra medida de contenção a essa sobrecarga é a intensificação do trabalho e dedicação de mais horas a este fim. Na entrevista concedida pelo ministro Eros Grau, ele revela ter dedicado de quatorze a quinze horas de trabalho por dia na tentativa de diminuir a quantidade de processos que existia em seu gabinete (FONTAINHA; MAFEI; ACCA, 2016, p. 77). No entanto, o deslocamento de processos que representem conflitos entre leis federais, diminuindo a sobrecarga do Supremo, e a dedicação de mais horas de trabalho podem não ter sido o bastante, uma vez que parcela da sobrecarga de trabalho é adquirida no momento de posse com a herança do gabinete do ministro antecessor. E além do ministro recém-chegado herdar os processos de seu antecessor, ocorre ainda o que o ministro Sepúlveda Pertence chama de "avalanche de processos", fazendo referência aos planos econômicos de governos anteriores (FONTAINHA; SILVA; NUÑEZ, 2015, p. 96-98) e que é capaz de ocorrer em diferentes momentos da história brasileira.

Apesar de o desconforto com a quantidade de processos apreciada pelo Supremo, o ministro Sepúlveda Pertence, além de afirmar não conseguir dedicar atenção a cada um deles como gostaria, destaca que a chamada prática do "assinar sem ler" ocorre principalmente nos conhecidos como "processos repetitivos" (FONTAINHA; SILVA; NUÑEZ, 2015, p. 99), fazendo referência às demandas cujas razões e objetos de análise são semelhantes, comuns entre si, citando como exemplo os planos econômicos. $\mathrm{Na}$ hipótese, bastava uma decisão sobre uma demanda que integrasse um determinado grupo dos processos repetitivos para ser aplicada igualmente a todos os outros processos. Essa foi uma medida adotada pelos ministros para melhor lidar com a 
quantidade de processos que gerava tanto desconforto para cada um deles. Além dessa, outras medidas foram adotados por ministros do Supremo para atribuir maior celeridade na prestação jurisdicional. Veremos algumas delas nas linhas a seguir:

Na entrevista concedida pelo ministro Ilmar Galvão, ao rememorar o caso dos expurgos inflacionários, menciona medida institucionalmente criada para os ministros lidarem com a quantidade de processos sobre a matéria, o chamado "julgamento por despacho", em que os ministros poderiam decidir o caso se o plenário já tivesse decidido, antes, casos idênticos. Ou seja, não precisava mais submeter tais casos ao plenário. Tal medida poderia inclusive estimular a discussão a respeito da criação da decisão monocrática pelos próprios ministros do Supremo, prática costumeira à época do ministro Ilmar Galvão (inclusive à revelia do regimento), que ocupou a vaga de ministro do Supremo no período de 1991 a 2003 (FONTAINHA; MAFEI, 2016, p. 110111).

Além dessa medida, outra também adotada pelos ministros do Supremo é a conhecida como "pertinência temática" que, para o ministro Célio Borja, parecia não fazer sentido para o motivo ao qual foi justificada. Afirma o ministro que a pertinência temática foi criada a partir de uma preocupação dos próprios ministros com o aumento gradual do número de processos no Supremo. E a pertinência temática exercia a função de diminuir o número de recursos na Corte (FONTAINHA; DA SILVA; GUIMARÃES, 2015, p. 86-87).

Além das estratégias citadas para melhor gerir a quantidade de processos que cada gabinete dos ministros possuía, outra medida foi adotada para ser aplicada às demandas repetitivas, como a mencionada na entrevista concedida pelo ministro Sydney Sanches, que afirma ter se utilizado de um modelo de decisão em casos repetitivos (FONTAINHA; MATTOS; SATO, 2015, p. 157-158), destacando o que diversos ministros apontam em suas entrevistas: a maioria dos processos constantes nos Supremo tratam-se de demandas repetidas. Para lidar também com processos desta característica, uma das medidas foi julgar uma dessas demandas, utilizar a sua decisão como referência e modelo, e aplicar aos demais casos que se equipararem a ela (FONTAINHA; MAFEI, 2016, p. 110-111).

Diferente de medidas institucionalmente adotadas pelos próprios ministros, algumas medidas legislativas também foram adotadas, como a emenda constitucional

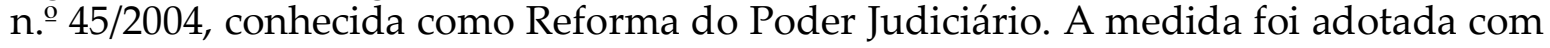
o objetivo de diminuir o número de recursos a serem apreciados pelos ministros do Supremo atribuindo-lhes o reconhecimento do critério da repercussão geral das questões constitucionais debatidas e a súmula vinculante, hipótese em que o supremo poderia criar um verbete que representasse decisões proferidas no passado e que obrigaria juízes, tribunais e toda a Administração Pública a segui-las (FONTAINHA; ALMEIDA, 2016, p. 73-75).

Mas, quando perguntados se as medidas criadas teriam resolvido o problema da grande quantidade de recursos, os ministros se mostravam enfáticos em afirmar que não, apesar de destacar o positivo papel que cada uma das medidas criadas possuía no tribunal. Por exemplo, em relação a repercussão geral, o ministro Sepúlveda Pertence destaca que por se tratar de processos com "causas relevantes", as demandas 
provocam sustentação oral no Supremo, que ainda não se preparou para esse tipo de ocorrência (FONTAINHA; SILVA; NUÑEZ, 2015, p. 96-98).

Somada a questão destacada pelo ministro Sepúlveda Pertence, encontra-se ainda o chamado sobrestamento que, quando o Supremo identifica o requisito da repercussão geral em determinada demanda, imediatamente as que lhes são semelhantes ficam paralisadas nos respectivos tribunais aguardando o julgamento do Supremo (FONTAINHA; ALMEIDA, 2016, p. 73-75) e inflacionando os Tribunais de Justiça. Somados à repercussão geral, os ministros entrevistados também destacam que a súmula vinculante também não é capaz de resolver ou diminuir quantidade de processos que existem no Supremo (FONTAINHA; DA SILVA; DE ALMEIDA, 2015, p. 121-122).

As questões aqui destacadas representam apenas parcela da preocupação e desconforto dos ministros do Supremo com o desenvolvimento de suas atividades, capazes de influenciar diversos seguimentos das sessões de julgamento, como o "selo" colocado pelo Supremo em algumas causas consideradas relevantes (quando reconhecida o requisito da repercussão geral), algo que somente o plenário pode fazer. As medidas citadas pelos ministros como gestoras da quantidade de processos que existem em seus gabinetes demonstram reconhecimento acerca da necessidade de práticas capazes de maximizar as atividades por eles desempenhadas, além de melhorar a prestação jurisdicional.

A quantidade de processos acumulados nos gabinetes de cada um dos ministros parece exercer influência direta ao exercício da colegialidade ${ }^{5}$, uma vez que, ao invés de ministros dedicarem tempo ao estudo e aprofundamento de demandas levadas ao colegiado para discussão e análise conjunta dos próprios ministros, os mesmos precisam necessariamente dedicar tempo à criação de estratégias que melhor administrem a celeridade da prestação jurisdicional devido o número alto de processos sob a sua responsabilidade. Isto é, pode ser que a opção dos ministros pela celeridade da prestação jurisdicional não represente também uma análise mais profunda e cuidadosa de cada um dos casos que estão sob a sua responsabilidade. Além disso, outra questão merece especial relevo no presente tópico, como o excesso de trabalho capaz de impedir o diálogo e elaboração conjunta de decisões. O que poderá ser mais bem notado no tópico seguinte, que será destinado às práticas citadas pelos ministros para organizar a sua força de trabalho, como montagem de seu gabinete, distribuição de funções, elaboração de votos, dentre outras questões.

\section{Organizando a força de trabalho: entre atividades mecânicas e o esforço em fazer raciocínios jurídicos}

No tópico anterior foi possível notar o empenho de ministros em implementar técnicas criadas especificamente para lidar com a quantidade de processos existente em cada um de seus gabinetes. Algumas técnicas são utilizadas inclusive durante as

\footnotetext{
5 Sobre o tema, ver artigo do mesmo autor e que dialoga diretamente com o atual, chamado: "A colegialidade nos tribunais: quando uma ideologia vira dogma e o dogma um princípio", publicado na Revista Estudos Institucionais, v. 3, n. 1, 2017.
} 
sessões de julgamento, como a pertinência temática, por exemplo. Ou seja, enquanto algumas técnicas são criadas no ambiente externo às sessões de julgamento, aparentando ter o objetivo de atribuir dinâmica diferente ao colegiado (por exemplo, a apreciação e julgamento do que consideram como "causas relevantes"), outras são desenvolvidas durante as próprias sessões, com aparência de sofisticadas teses jurídicas, mas com objetivo diverso do preconizado pela corte durante a sessão de julgamento.

Além do empenho de ministros em criar meios para melhor lidar com a quantidade de processos que lhes causam o desconforto demonstrado em tópico anterior, após serem impactados pela quantidade de trabalho que possuem no seio de suas atividades, a medida seguinte é organizar a força de trabalho que possuem, quer seja montando o gabinete e recrutando seus assessores, aplicando as técnicas anteriormente criadas, ou estabelecendo critérios para atribuir prioridade à apreciação e julgamento de determinadas demandas. As linhas a seguir terão por objetivo demonstrar como ministros organizam sua força de trabalho para melhor desempenhar suas funções mais primordiais: proferir votos que resultem em decisões judiciais muitas vezes irrecorríveis, por se tratar da última instância do Poder Judiciário brasileiro.

Assim, o presente tópico apresentará, por meio do empenho dos ministros em organizar a sua força de trabalho, diferentes técnicas e estratégias principalmente de gestão em seu gabinete, capazes de combater uma das maiores críticas que o Poder Judiciário tem recebido nos últimos anos: a sua morosidade. Mas o acúmulo de processos em seus gabinetes e o modo como organizam a sua força de trabalho pode estimular o desenvolvimento de um trabalho mais isolado de cada um dos ministros, tornando mais difícil a produção de decisões coletivas. Em outras palavras, a dificuldade em produzir decisões coletivas no Supremo, devido à quantidade de trabalho de cada um de seus ministros, estimula a produção de decisões individuais manifestadas nos votos que, somados, se transformará em uma decisão que represente todo o colegiado.

Assim que o ministro recém-chegado é empossado, a primeira medida para dar início ao seu trabalho é conhecer o gabinete que assumirá de seu antecessor. Ao "herdar" o gabinete, e consequentemente manter algumas de suas características conforme será visto nas próximas linhas, é precisa imprimir uma dinâmica específica de trabalho, o que pode variar desde a imposição de técnicas próprias de trabalho, manter as que já existiam quando o ministro antecessor estava no cargo, ou importar técnicas de gabinetes que possua algum contato. A visão impressa aos gabinetes por seus ministros são as mais variadas, alguns o associam a uma linha de montagem de fábrica (FONTAINHA; ALMEIDA, 2016, p. 59-60), outros o aproximam de uma microempresa (FONTAINHA; DA SILVA; DE ALMEIDA, 2015, p. 123). Essa visão importará no modo de condução das atividades que ali serão desenvolvidas. Um dos primeiros passos ao início de todo esse processo é a seleção do pessoal de apoio, em outras palavras, o recrutamento dos assessores.

Mas para dar início à seleção do pessoal de apoio é preciso verificar o quanto a estrutura dos gabinetes é capaz de dar suporte à equipe que se deseja criar. $\mathrm{O}$ ministro Moreira Alves, ao descrever a sua estrutura de trabalho assim que iniciou suas

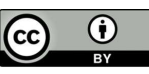

5 JOURNAL OF INSTITUTIONAL STUDIES 1 (2019)

Revista Estudos Institucionais, v. 5, n. 1, p. 171-216, jan./abr. 2019 
atividades no Supremo, destaca que não teve mais de dois assessores ao longo do período em que esteve no Supremo. E um dos motivos estava relacionado às condições estruturais dos gabinetes, que não suportavam mais do que o que já existia em sua época de ministro. Apesar das condições estruturais do ambiente de trabalho, o ministro Moreira Alves afirma que ainda que suportassem mais assessores, poderia não fazer muita diferença, uma vez que elaborava relatórios e votos sozinho (FONTAINHA; DE PAULA; ALMEIDA, 2015, p. 72-75).

Atualmente, com uma estrutura capaz de suportar equipes maiores, consequentemente, o número de profissionais que passaram a compor a equipe de trabalho dos ministros dentro de seus gabinetes aumentou. Independentemente do tamanho da equipe, nas próximas linhas poderá ser notado que existem características comuns entre os membros da equipe formada pelos ministros recém-chegados ao Supremo. A primeira observação é a de que, ao assumir o gabinete, alguns pedidos são atendidos, quer seja dos ministros antecessores ou de ocupantes de cargos públicos que desejavam ver determinada pessoa integrando a equipe de trabalho do ministro recém-chegado. Por exemplo, assim que foi empossado, o ministro Rafael Mayer afirma ter recebido pedidos para manter um assessor de seu antecessor, além de colocar no cargo uma esposa do comandante da polícia militar de Brasília à época e uma outra pessoa que lhe foi indicada. Isto é, dos quatro assessores a que tinha direito, três foram provenientes de pedidos e indicações (FONTAINHA; MATTOS; NUÑEZ, 2015, p. 63-64).

Forma diversa de montagem de uma equipe de apoio pelos ministros do Supremo é a opção por manter os assessores de seu antecessor, o que pode ocorrer por diversos motivos, como a manutenção de um ritmo de trabalho que o ministro recém-chegado considera adequado e eficiente, a necessidade de dar início às suas atividades com a maior brevidade possível ou até mesmo ter o conhecimento restrito de pessoas que poderiam assumir o cargo tão prontamente fosse empossado. Ainda que o ministro recém-chegado tenha mantido a estrutura de gabinete de seu antecessor, também há de se considerar a necessidade que possuem em atribuir características mais próximas das que consideram ideais ao exercício de suas atividades, como escolher o seu próprio chefe de gabinete, por exemplo (FONTAINHA et al., 2016, p. 199-200).

Com a montagem do gabinete a partir de pedidos, indicações e manutenção da equipe de seus antecessores, diversos ministros têm optado também por inserir em seu corpo qualificado de assessores profissionais que tenham tido maior relação, contato e confiança no desempenho das funções, como integrantes da equipe de trabalho anterior à chegada ao Supremo e, sobretudo, ex-alunos e orientandos de dissertações e teses em programas de pós-graduação stricto sensu em que sejam parte integrante do corpo de professores (FONTAINHA; VANNUCCHI; DOS SANTOS, 2016, p. 102-104), o que tem se tornado bastante comum entre os ministros do Supremo.

Por último, uma característica que parece estar sendo compartilhada entre os ministros entrevistados e que compõem uma época mais recente da corte é a de que o corpo de assessores é composto por pessoas mais jovens (FONTAINHA; MAFEI, 2016, p. 84-85), como alunos recém-formados ou iniciando estudos em programas de mestrado e doutorado, ainda que existam ministros que se posicionem de forma 
contrária à inserção de pessoas que possuam características mais acadêmicas dentre seus assessores (FONTAINHA et al., 2016, p. 199-200).

Após a montagem do gabinete com assessores quer sejam contratados ou mantidos a pedido, ou ex-alunos, orientandos ou colegas de um trabalho anterior, era preciso distribuir funções entre seus assessores para pôr em pleno funcionamento o gabinete que acabara de montar. A distribuição de funções entre os assessores é outra medida adotada por ministros do Supremo para imprimir maior rendimento às suas atividades na Corte. As funções de cada um dos assessores variam desde o estabelecimento anterior de uma relação de afinidade ou confiança, como a escolha de um chefe de gabinete, até a aptidão que cada um deles possui para lidar com as atividades que ali existem. Por exemplo, conforme visto anteriormente, alguns assessores são mantidos nos cargos ou contratados pelos ministros recém-chegados devido a habilidade técnica que possui para o desempenho de algumas funções, o que pode se justificar pela possível falta de tempo de treinamento que possuem, uma vez que a quantidade de trabalho existente pode não permitir que esse procedimento ocorra.

Além disso, de acordo com os depoimentos orais dos ministros entrevistados, foi possível inferir que lidar com processos repetitivos era uma competência a ser levada em consideração no momento de recrutamento dos assessores. Diversos ministros contam com apoio constante dos assessores para lidar com essas demandas e diminuir, assim, a sua quantidade de trabalho. $\mathrm{O}$ que pode inclusive considerar técnicas desenvolvidas para melhor administrar esse tipo de função, como o estabelecimento de uma triagem de processos, a utilização de decisões-modelo criadas pelos próprios ministros, dentre outras. Adiante serão demonstradas algumas funções desempenhadas pelos assessores para imprimir maior celeridade e eficiência na prestação jurisdicional.

Em todos os depoimentos orais acessados, há o estabelecimento de uma relação entre o trabalho desenvolvido pela assessoria e os chamados processos repetitivos, oportunidade em que ministros destacam a importância do trabalho desenvolvido por seus assessores na contenção de tais demandas. Entretanto, há o destaque de que uma das funções da assessoria de maior aceitação entre os ministros se trata do exercício de uma atividade mecânica, envolvendo também os ministros e gerando frustração quanto à expectativa em realizar algum raciocínio jurídico (FONTAINHA; SILVA; NUÑEZ, 2015, p. 98-99).

E o trabalho mecânico a que o ministro Sepúlveda Pertence faz menção refere-se prioritariamente à pesquisa de jurisprudência, doutrina (FONTAINHA; MATTOS; SATO, 2015, p. 108), com o destaque a um trabalho mais técnico como a elaboração dos relatórios de cada um dos casos apreciados e julgados pelos ministros (FONTAINHA; DE PAULA; NUÑEZ, 2015, p. 140-141).

Apesar de o trabalho técnico desenvolvido pelos assessores, os ministros são contundentes em afirmar que eles mesmos elaboravam seus votos (FONTAINHA; DE PAULA; ALMEIDA, 2015, p. 72-75), alguns deles sequer admitindo a hipótese de seus assessores terem conhecimento acerca de seu posicionamento antes de o caso ler levado ao plenário, sob pena de considerar tal postura como uma "terceirização da jurisdição” (FONTAINHA; DE PAULA; NUÑEZ, 2015, p. 140-141; FONTAINHA; 
ALMEIDA, 2016, 59-60). Isto é, apesar do trabalho de parceria com os ministros, poder ser que existam casos que os assessores sequer tenham acesso, como os considerados "realmente importantes", assim chamados pelo ministro Eros Grau ao estabelecer distinção entre processos e votos que são preparados dentro do gabinete e os que são fora dele (FONTAINHA; MAFEI; ACCA, 2016, p. 75).

Além das funções distribuídas a cada um dos assessores, os ministros buscavam também implementar outras técnicas capazes de maximizar as atividades desenvolvidas no gabinete, demonstrando o tempo como uma variável bastante considerável na condução das atividades dos ministros, principalmente na organização de sua força de trabalho. A utilização de decisões-modelo aos processos repetitivos são bons exemplos desse processo (FONTAINHA; DA SILVA; DE ALMEIDA, 2015, p. 123; FONTAINHA; DE PAULA; NUÑEZ, 2015, p. 141-142). O que não impedia a criação e aplicação de diversos outros mecanismos capazes de imprimir maior celeridade e também qualidade no desenvolvimento das atividades de cada um dos assessores. É possível citar como exemplo a postura adotada e descrita pelo ministro Luiz Fux com os seus assessores:

[FF] - Quantos são no seu gabinete?

[LF] - Não. Essa tropa de choque, assim, minha, meu Bope, ali [risos], meu Bope, tem uns cinco. Garotada de cabeça... Todos de cabeça boa. Falam vários idiomas, pesquisam tudo. Quem dá a linha sou eu. Por exemplo: Ficha Limpa Um. Todo mundo palpitando. Eu falei: “Tudo bem. Vamos fazer o seguinte: quem me convencer que à regra do artigo 16 é possível sobrepor-se o princípio, ganha o jogo". Vamos debater aqui. Não deu para saída. Porque como é que se vai pegar a regra constitucional e anular a regra constitucional? Entre uma regra constitucional e um princípio, não tem como a regra constitucional não prevalecer. Então, é assim. Mas, às vezes, vira debate, e, às vezes, eles preparam a pesquisa. Quando chego lá no plenário ou chego em casa, eu leio e, se não gosto, eu mudo. (FONTAINHA; VANNUCCHI; NUÑEZ, 2016, p. 115-117)

O trecho da entrevista concedida pelo ministro Luiz Fux pode demonstrar que, apesar do trabalho mecânico que muitos assessores possuem, assim como os ministros, o contato e proximidade entre eles pode também ser capaz de estimular proposições de soluções ao concretamente analisado pelo ministro, muito embora possa ecistir uma hierarquia até mesmo entre os próprios assessores (LEWANDOWSKI, 2015, p. 95-96). Isto é, cada ministro tem a sua forma de organização do ambiente de trabalho e dos recursos que dispõem para melhor desenvolver suas atividades. O objetivo será sempre o de acelerar e tornar mais qualificada a prestação jurisdicional.

Mas como não existe um padrão de organização dos gabinetes e cada ministro possui autonomia para gerenciar todo esse processo, pode ocorrer de existirem gabinetes caracterizados pela falta de organização, capaz de gerar consequências 
negativas tanto diante de uma análise quantitativa como qualitativa (FONTAINHA; ALMEIDA, 2016, p. 64-65).

No trecho indicado, o ministro Ilmar Galvão estabelece uma relação entre a morosidade do Poder Judiciário e a organização dos gabinetes dos ministros, citando como exemplo um caso que demorou dois anos no gabinete de um ministro até ser provocado pela parte por uma manifestação a seu respeito. Como resposta, foi proferido despacho pelo ministro: "indefiro.". Outro ministro a também alertar à má gestão dos gabinetes é o Aldir Passarinho, que destaca não ser incomum assessores diferentes apreciando demandas de mesmo teor jurídico e fixando entendimentos diversos uns dos outros, o que permitiria que um mesmo juízo apresentasse dois entendimentos acerca de uma mesma matéria (FONTAINHA; SATO, 2015, p. 50-51).

Para evitar esses tipos de eventos, o ministro Ilmar Galvão informa que havia um grupo de funcionários responsáveis por fazer uma triagem inicial dos processos que entravam lá diariamente. Os processos sobre matérias já apreciadas pelo Supremo eram de responsabilidade da assessoria. Os processos cujo destino eram a Procuradoria da República eram encaminhados no mesmo dia. Além disso, um assessor era responsável só por agravos de instrumento; matéria nova e pedidos de vista eram direcionados diretamente para a casa do ministro. Em relação aos pedidos de vista, o ministro afirma que ele os apreciava rapidamente para não dar tempo de nenhuma das partes despachar a respeito com ele. Assim, pedia vista dos autos em uma sessão, e, na seguinte, já devolvia o processo e o colocava em mesa para julgamento e manifestação de seu voto (FONTAINHA; ALMEIDA, 2016, p. 59-62).

A triagem feita no recebimento de novas demandas, no entanto, não resolvia outro problema comum nos gabinetes dos ministros: a inexistência de um critério capaz de atribuir prioridade de determinados processos em detrimento de outros, o que estaria diretamente relacionado ao tempo esperado pelas partes para terem sua demanda apreciada e julgada. Em entrevista concedida pelo ministro Cezar Peluso, ao fazer referência ao tempo médio em que cada ministro fica com um processo em seu gabinete, o ministro afirma que, devido ao alto volume de processos, ministros precisam estabelecer critérios para selecionar que casos devem apreciar na frente de outros. Um dos critérios utilizados pelo ministro Peluso era a antiguidade. Mas não nega que atribuía prioridade para alguns processos que, por meio de sua leitura e análise, considerava mais importante que outros, quer fosse pelo seu tempo de espera por uma manifestação ou em razão da complexidade da matéria, ou ainda pela sua repercussão pública (FONTAINHA; DA SILVA; DE ALMEIDA, 2015, p. 137-140).

Acrescidos aos critérios sugeridos pelo ministro Cezar Peluso, mais um é sugerido pelo ministro Ilmar Galvão: o estabelecimento de prioridade aos processos em que o demandante está na iminência de ir à prisão. Mas a sugestão dada pelo ministro apresenta um tom de reflexão sobre o assunto, afirmando que o Poder Judiciário brasileiro deve e tem condições de enfrentar. E a inexistência de critérios gera, por exemplo, os pedidos de preferência por políticos ou autoridades públicas, devido principalmente a morosidade do Poder Judiciário brasileiro (FONTAINHA; ALMEIDA, 2016, p. 63-64). Ou seja, percebendo a fragilidade do Poder Judiciário em lidar com o tema, envolvidos direta e indiretamente em demandas que estão sob o 
poder e análise de ministros do STF passaram a fazer pedidos frequentes de prioridades.

Uma das consequências de o Poder Judiciário, ou cada um dos ministros do STF, se manifestar a respeito de critérios adotados para estabelecer prioridade de trâmite a algumas demandas em detrimento de outras é o de estar criando um meio de destacar processos, casos que sejam considerados mais importantes que outros. O que acontece invariavelmente dentro dos gabinetes quando adotados meios de organização das atividades desenvolvidas por assessores e ministros. Somente neste tópico, é possível identificar diversos exemplos de como alguns processos ganham destaque em relação a outros, mas nunca de forma oficial, institucionalizada. O que ressalta a necessidade de investigar também a ocorrência de como ministros identificam processos mais importantes que outros.

O próximo tópico será responsável por demonstrar como os ministros, nas entrevistas concedidas ao projeto História Oral do STF, identificam que processos podem ser mais importantes que outros a partir, principalmente, da relação estabelecida com a mídia, imprensa e opinião pública. Deste modo, a questão que se insurge no seio dessa investigação será a de como os ministros conseguem identificar processos mais importantes, atribuindo-lhes tratamento diferenciado, mas sem colocar em risco a imparcialidade do julgamento. Em outras palavras, neste tópico foi possível inferir que um caso importante deverá ter prioridade, preferência de julgamento em relação a outras demandas; no próximo será possível identificar critérios que permitam atribuir ou reconhecer importância a alguns processos, além do esforço em julgá-lo sem mitigar sua imparcialidade a partir de toda a relação estabelecida pelo Supremo com a mídia, imprensa e opinião pública.

\section{SEGUNDA DIMENSÃO: A CONSTRUÇÃO DA RELEVÂNCIA E O CONTROLE DA IMPARCIALIDADE}

A inexistência de critérios institucionais utilizados em igual medida por todos os ministros do Supremo para procederem a uma triagem dos processos que já existem nos gabinetes, somados aos que chegam diariamente, estimulou ministros a criar diferentes iniciativas para identificar processos que por algum motivo devem ter preferências em sua tramitação se comparados a outras demandas. Essa distinção entre processos gerou dentre os próprios ministros a discussão acerca de quais casos poderiam ser considerados importantes ao destacar alguns em relação a outros. E nas entrevistas concedidas ao projeto HOSTF, diversos ministros manifestaram-se no sentido de utilizar alguns critérios para identificar tais casos. No entanto, por meio da leitura dos depoimentos orais concedidos foi possível perceber algumas outras questões que serão igualmente abordadas no presente tópico.

A primeira delas refere-se à existência de possíveis pressões geradas quer seja pela mídia, imprensa, opinião pública e até mesmo amigos e familiares no sentido de ministros votarem em determinado sentido. Os próprios ministros confessam a ocorrência de diversas dessas pressões, muito embora afirmem não surtir o efeito desejado por aquele que faz a pressão. Apesar das entrevistas abordarem 
especificamente como os ministros identificam um processo importante/relevante dentre diversos outros aparentemente repetitivos, ao destacarem a existência de diversos tipos de pressões sofridas pelos próprios ministros, uma nova visão pode ser impressa ao mesmo cenário: a busca e compreensão de quem define quais casos são importantes: ministros e/ou assessores no momento da triagem realizada; ou mídia, imprensa e opinião pública'?

Por outro lado, exercendo igualmente pressões, mas destacado pelos próprios ministros como sendo "pedidos de preferência" ou prioridade na apreciação e julgamento, e nunca por voto em um determinado sentido, é possível identificar pedidos formulados por advogados, políticos ou alguma parte interessada. O que inclui novos atores na compreensão deste cenário que aqui está se desenhando, como a compreensão do que seriam casos importantes. Pode ser também que todos os atores aqui destacados tenham parcela de contribuição na identificação de tais casos, o que não permitiria a utilização de um raciocínio lógico ou uma inferência para "descobrirmos" quais casos apreciados pelos ministros podem ser considerados importantes. Ou seja, buscando identificar quais casos apreciados pelos ministros do STF são importantes, passando pela reflexão de quem poderia destacar os casos mais importantes apreciados no Supremo, poderíamos alcançar uma nova discussão: como a relevância é construída no Supremo.

Essa será uma discussão que, embora surgida pela primeira vez no presente tópico e relacionada diretamente à atribuição ou reconhecimento da importância de determinado processo, poderá ainda se estender em alguns outros momentos da pesquisa ora desenvolvida. E, ao menos no presente tópico, não será possível dissociar a presente discussão do exercício e controle da imparcialidade que os julgadores precisam ter na apreciação das questões que lhes são demandadas. Nesse sentido, algumas situações como a aqui abordada podem ter contribuído à identificação de um dos possíveis cenários em que a discussão acerca da construção da relevância no Supremo se faz presente: ao mesmo tempo em que os ministros demonstram estar estabelecendo relações cada vez mais próximas com a mídia e imprensa a fim de destacar estarem atentos aos anseios populares, precisam demonstrar também que a imparcialidade do magistrado continua sendo uma garantia do cidadão.

Sendo assim, as linhas a seguir destacarão alguns trechos de entrevistas concedidas pelos ministros do Supremo de modo a ressaltar alguns dos critérios que afirmam utilizar para identificar um caso importante dentre todos aqueles que já existem em seus gabinetes, além dos que chegam diariamente; destacar as pressões que um ministro do Supremo precisa superar para apreciar e julgar um caso (importante ou não) de forma imparcial; e demonstrar aproximações entre os ministros do Supremo e a mídia e imprensa, além de possíveis consequências dessa relação que parece ter sido construída recentemente.

\footnotetext{
${ }^{6}$ A opinião pública no sentido atribuído ao presente tópico deve ser entendida como abrangendo opiniões difusas e organizadas quer seja por amigos, familiares e até mesmo redes sociais, mídias eletrônicas, dentre outras.
}

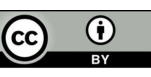




\section{Quem define qual caso é importante?}

Nos depoimentos orais concedidos pelos ministros do Supremo é possível notar uma descentralização das atividades desempenhadas pelos próprios ministros, direcionando aos seus assessores o cumprimento de algumas tarefas, como a triagem de processos - hipótese em que se verifica quais processos são repetitivos ou se referem a casos novos. A triagem dos processos, conforme veremos nas páginas a seguir, poderá nos apresentar diferentes mecanismos de identificação de um processo importante, se comparado aos demais. O que pode importar no modo como ele será discutido e notado na sessão de julgamento às portas abertas, gerando influências diretas ao exercício da colegialidade. Em entrevista concedida pelo ministro Eros Grau, há o destaque que a competência aqui descrita foi delegada aos seus assessores, aos quais se tornaram responsáveis por identificar quais casos, dentre os repetitivos, tratava-se de questão ainda não apreciada e julgada pelo Supremo. Hipótese diversa é descrita pelo ministro Eros Grau ao noticiar a chegada, em seu gabinete, de um processo novo:

[FF] - Como é que o senhor distinguia os processos que o senhor deveria dar essa atenção, como o caso da anistia, que seus assessores sequer viram. Você fez 100\%, e aqueles que... Eventualmente, existem processos que o senhor só assinava, passava uma vista d'olhos?

[EG] - Processos que eram repetitivos, eu passava uma vista d'olhos... Mas isso vinha pelos assessores e pela chefia de gabinete.

$[\mathrm{FF}]$ - E a escolha desses mais... Que o senhor ia dar...?

[EG] - Das duas, uma: ou eu mesmo sabia, já por notícia que chegava, ou na triagem que os assessores faziam: "Olha, isso aqui é um caso novo; isso daqui é repetitivo."

Apesar de não revelar o modo como a notícia poderia ter chegado ao seu conhecimento em relação à existência de um "caso novo" em seu gabinete, os demais ministros entrevistados alegam existirem "casos paradigmáticos", em que se é reconhecida maior repercussão se comparados a outros processos. Os chamados "casos paradigmáticos", que representa apenas uma das formas aos quais os ditos casos importantes são também conhecidos, são caracterizados por serem mais graves e, portanto, de maior importância. Dito de outro modo, nas entrevistas concedidas pelos ministros do Supremo, um dos critérios surgidos para identificar um caso importante seria o do reconhecimento de sua repercussão, o que o tornaria um processo mais importante (FONTAINHA et al., 2016, p. 196).

Apesar de os casos de maior repercussão pública serem considerados mais importantes que os demais, inclusive tendo prioridade em sua apreciação, os ministros não deixam claro aqueles que contribuem para que um determinado caso tenha mais repercussão pública se comparados a outros: a repercussão seria dada pela imprensa ou reconhecida pelo próprio ministro no momento de leitura e análise de cada um dos processos (FONTAINHA; DA SILVA; DE ALMEIDA, 2015, p. 140-142). 
Em resumo, o reconhecimento da repercussão pública pode ser um critério a ser levado em consideração no momento de caracterização de um caso como importante, o que pode ocorrer antes mesmo de o ministro apreciar o processo, uma vez que ele pode receber a notícia de que apreciará um caso importante antes dele chegar ao seu gabinete (assim que distribuído, por exemplo) ou ter a informação por meio de seus assessores após triagem feita. Além desse, outros critérios também comentados pelos ministros para identificar processos importantes seriam aqueles que, embora não possuam maior repercussão pública, são importantes para o julgador promover justiça, o que só ocorreria após leitura e análise do processo (FONTAINHA; DA SILVA; GUIMARÃES, 2015, p. 78-79).

De acordo com os depoimentos orais consultados, é difícil identificar claramente se a chamada "repercussão pública" de determinados processos passou a ser reconhecida com mais frequência a partir de uma aproximação maior do Supremo Tribunal Federal com a mídia, imprensa e opinião pública ou se o destaque dado a esses processos pelos próprios ministros e/ou assessores que proporcionaram essa maior aproximação. Esse ambiente em que se torna possível inferir indícios da construção da relevância no Supremo (como a seleção de casos considerados importantes) possui efeitos diversos: como a impossibilidade de atribuir precisão acerca daqueles que contribuem a esse processo, o que pode ocorrer dentro ou fora do próprio gabinete. Quando ocorre fora do gabinete, outra questão passa a merecer igual destaque: a concorrência da mídia, imprensa e opinião pública na concessão do status de um caso como importante poderia também ser considerada como uma estratégia para pressionar ministros a não apenas acelerar trâmites processuais, mas também influenciar julgamentos. O próximo tópico abordará mais detidamente algumas destas questões.

\section{As pressões difusas e o controle da imparcialidade}

No tópico anterior foi demonstrado que, apesar de alguns critérios utilizados para caracterizar um processo como importante serem reconhecidamente utilizados por ministros do STF, não existem critérios universalmente utilizados por eles. Cada gabinete possui autonomia administrativa para regular sobre suas próprias atividades, o que importa dizer que cada ministro identifica um caso importante de forma peculiar, não esclarecendo inclusive como um determinado critério é utilizado. Além de não existirem critérios universalmente utilizados, os que existem não são claros o bastante para permitir a compreensão de sua dimensão de funcionamento.

A inexistência de critérios universais, somados à falta de clareza a respeito dos que são utilizados pelos ministros, na concessão de ritos diferenciados a determinados processos (como a aceleração de seu julgamento), podem contribuir à existência das já mencionadas pressões para que ministros apreciem mais rapidamente determinados processos, bem como os julgue de determinada forma. Quando perguntados acerca da existência das referidas pressões, os ministros afirmam a sua ocorrência principalmente por meio da mídia, imprensa e opinião pública, mas não descartam também serem pressionados em ambientes familiares. No entanto, diversos ministros enfatizam não terem sido influenciados por tais pressões, como o ministro Ilmar Galvão na hipótese em que foi relator do conhecido como "Caso Collor" (FONTAINHA; ALMEIDA, 2016, p. 70-72).

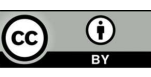

5 JOURNAL OF INSTITUTIONAL STUDIES 1 (2019)

Revista Estudos Institucionais, v. 5, n. 1, p. 171-216, jan./abr. 2019 
Ao declarar ter sofrido pressões para julgar de determinada forma, não esclarecendo qual tipo de pressão tenha sofrido, o ministro Ilmar Galvão destaca que o "Caso Collor", se comparado ao caso conhecido como "Mensalão", "era uma coisa insignificante". Essa declaração pode demonstrar que a caracterização de um caso como importante pode variar de acordo com a época em que se insere ou os personagens envolvidos, uma vez que o caso pode ter sido tratado como importante por fazer referência ao Presidente da República, e não devido a alguma complexidade da matéria. Além disso, os personagens envolvidos em determinada demanda podem contribuir à repercussão pública do mesmo processo gerando, consequentemente, pressões sobre o seu julgamento.

Ao fazer referência a outro caso que envolve contexto político e, sobretudo, o Presidente da República, o ministro Luís Roberto Barroso ao explicitar ter proferido um voto técnico, e não político, no "Caso do Mensalão", destaca ter agido de forma correta em proferir o seu voto e confessa que teria uma "vida mais fácil" se tivesse cedido às pressões familiares, amigos e imprensa, admitindo que sofreu pressões para votar de forma contrária (FONTAINHA; VANNUCCHI; DOS SANTOS, 2016, p. 113114).

Nos dois depoimentos aqui demonstrados, e em vários outros trechos de entrevistas que poderiam aqui ser inseridos (e que serão em tópicos seguintes) há uma clara insatisfação dos ministros com as pressões por eles sofridas, além da necessidade de demonstração de que as pressões não influenciam seus votos. A aproximação dos ministros com a mídia, imprensa e opinião pública, o aumento da concessão de entrevistas, os constantes comentários acerca de casos podem também ter o condão de demonstrar o exercício da imparcialidade em casos como os aqui referidos, o que não significa que não existam momentos em que o ministro se permita influenciar por algum aspecto capaz de conduzir o seu voto. Por exemplo, ao destacar a possibilidade de já ter sido solicitado para votar em determinado sentido, o ministro Eros Grau descreve dois casos em que ficou sensibilizado com a história dos demandantes e quis dar uma decisão que lhes favorecessem, destacando que tal postura não poderia ocorrer sempre, sob pena de o juiz ter o dever de se declarar impedido (FONTAINHA; MAFEI; ACCA, 2016, p. 78-80).

Nesse trecho, o ministro Eros Grau afirma a existência de outro tipo de pressão exercida sobre os ministros: a dos advogados que, por meio do desenvolvimento de argumentos, tentam induzir o ministro a determinado juízo. Mas não atribui nenhuma conotação negativa a essa prática e afirma nunca ter recebido qualquer outra forma de pressão por votos. Apesar disso, afirma que já se influenciou e envolveu emocionalmente com determinados casos, hipótese em que teve o desejo em votar de determinada forma. No entanto, para o ministro Eros Grau, as hipóteses por ele descritas em que ocorreu tal prática não poderiam ter qualquer conotação negativa, uma vez que não se tratava de um caso de repercussão pública e o seu desejo era o de "encontrar uma solução justa", "fazer justiça". Apesar da postura descrita, o ministro Eros Grau afirma também que ela não poderia se tornar constante, sob pena de o magistrado ter o dever de se considerar impedido de votar devido, possivelmente, o não exercício da imparcialidade na condução do caso. O esforço em demonstrar estar imune às pressões pode, por outro lado, ser entendido como uma medida de proteção 
e justificação ao próprio convencimento, porque ele precisa ser demonstrado no colegiado, ainda que se acompanhe o relator, considerando que não se acompanha apenas a parte dispositiva do voto, mas também a sua fundamentação. Daí a necessidade em se criar mecanismos e adotar posturas de controle à sua imparcialidade., conforme notado em linhas anteriores.

Enfim, a relação estabelecida entre a identificação de casos importantes, a existência de pressões por apreciação e julgamento de processos parecem ter relação estreita com o exercício da imparcialidade do magistrado a partir da análise dos depoimentos concedidos pelos ministros do Supremo. E essa parece ser uma relação estabelecida principalmente a partir da aproximação dos próximos ministros com a mídia e imprensa nos últimos anos, situação controvertida entre os próprios ministros. Há aqueles que consideram tal aproximação negativa, prejudicando o seu principal ofício: julgar. Por outro lado, alguns são partidários da ideia de que a referida aproximação é capaz de aproximar o tribunal dos anseios populares, atribuindo-lhe uma conotação positiva e concedendo-lhe uma legitimação democrática. Mas, apesar das conotações positivas e negativas, as aproximações aqui descritas não são claras e constantes, sendo capaz de gerar consequências como o estremecimento das relações entre os próprios ministros. Essas questões serão mais bem construídas no tópico seguinte.

\section{A aproximação do STF com a mídia e imprensa}

Atualmente, não é incomum nos depararmos diante de uma mídia eletrônica, rádios ou jornais televisivos e recebermos uma notícia que envolva diretamente o Supremo Tribunal Federal. Além disso, as notícias que eventualmente envolvam o tribunal, em diversos momentos, são veiculadas a partir da declaração de um ministro à imprensa, o que demonstra uma intensificação das relações social e institucionalmente estabelecidas entre o órgão máximo do Poder Judiciário e a mídia e imprensa. No entanto, durante os depoimentos orais concedidos pelos ministros do Supremo, há declarações afirmando que o atual momento representa uma relação bastante diferente entre o STF e imprensa, se comparados a anos anteriores. Na época em que exerceu o cargo de ministro do Supremo, o ministro Célio Borja afirma que não havia qualquer relação entre o Supremo Tribunal Federal e a mídia e imprensa, nunca sendo convidado a conceder entrevista, por exemplo (FONTAINHA; DA SILVA; GUIMARÃES, 2015, p. 81-82).

$\mathrm{E}$, em se tratando de um fenômeno recente, devido a heterogeneidade dos ministros que compõem a corte, é compreensível que existam ministros que se coloquem contrários a tal aproximação. Por outro lado, alguns ministros veem a aproximação da instituição com a mídia, imprensa e opinião pública de forma até bastante positiva, conforme veremos a seguir. De todo modo, os ministros que tomaram posse antes da criação da TV Justiça - um dos principais estimuladores desta aproximação segundo os próprios ministros -, ainda apresentam alguma resistência em relação à referida aproximação, mesmo depois de aposentados. A visão negativa que alguns ministros têm a esse respeito se dá principalmente à recente postura de alguns magistrados em conceder entrevistas, comentar casos, adiantar votos... Esta última, na visão do ministro Moreira Alves seria uma das consequências dessa recente 
relação estabelecida entre STF e imprensa (FONTAINHA; DE PAULA; ALMEIDA, 2015, p. 85).

Apesar da resistência principalmente dos ministros mais antigos, outros atribuem uma conotação positiva a tal aproximação considerando que a proximidade das decisões proferidas pelo Supremo com os anseios populares lhe conferiria uma legitimação democrática. Isto é, se por um lado, a exposição do magistrado seria considerada um problema para os magistrados, podendo influenciar em seu principal ofício: julgar; para outros, poderia ser entendida como uma tentativa de magistrados proferirem decisões que se adequariam mais às necessidades públicas. A questão que enfrenta maior resistência é a do magistrado pautar a sua decisão na opinião pública, considerada como uma das diversas pressões que sofre, o que comprometeria o exercício da imparcialidade.

No depoimento oral concedido pelo ministro Luiz Fux, o ministro destaca a importância de a decisão judicial estar consoante à opinião pública, mas lembra que o juiz não deve se ater a elas, porque ele deve julgar de acordo com os seus conhecimentos e ensinamentos. Para o ministro, não deve a decisão judicial se pautar na opinião pública, mas é importante se atentar para quando elas coincidem. Quando diante de casos mais emblemáticos, como a situação por ele descrita, o ministro afirma que o juiz votaria com ainda mais intensidade:

[LF] (...)E o princípio, o que é que é? É o começo de tudo. O princípio é o começo de tudo. Até afirma-se que o fogo dos vulcões, eles aparecem no cume, mas eles nascem no centro da terra. É ali embaixo que começa. Então, a aplicação axiológica do Direito, valorativa do Direito, ela permite que o juiz, digamos assim, edifique uma decisão que se aproxima da ética, da legitimidade, da aspiração popular. E é importante. Isso é que é importante esclarecer. É muito importante quando a decisão judicial coincide com a aspiração popular. Uma coisa é pautar sua decisão pela opinião pública. Daí, o juiz está abdicando do seu dever de julgar de acordo com os seus conhecimentos, seus ensinamentos. Outra coisa é a decisão judicial estar consoante à expectativa popular. Porque isso confere à decisão judicial uma legitimação democrática, uma confiança legítima no povo, que é algo importantíssimo. Há vários casos históricos, até de renúncia de presidente de Suprema Corte, por descumprimento de decisão judicial. Porque se o povo não acredita na decisão, não cumpre.

(...)

Então, por exemplo, num processo objetivo, discutem-se valores, é preciso ouvir a sociedade, claro. Marcha da Maconha. Vamos ver como é que a sociedade entende isso. Olha aqui. A Marcha da Maconha não é para as pessoas saírem fumando maconha. É uma liberdade de opinião, de expressão. Não pode levar criança, porque a Constituição Federal estabelece que o cidadão tem que ter cuidado com a educação da criança.

$[\mathrm{FF}]-\mathrm{O}$ senhor foi relator desse processo. 
[LF] - Da Marcha? Não, não. Eu votei. Porque, nesses casos mais emblemáticos, o juiz vota com mais intensidade. (...). (FONTAINHA; VANNUCCHI; NUÑEZ, 2016, p. 75-76)

Independentemente dos aspectos positivos ou negativos que ministros apontem em relação a proximidade maior entre STF e imprensa, mídia e opinião pública, é inegável que essa relação gera consequências. E uma das consequências relatadas pelo ministro Sepúlveda Pertence em relação aos atuais ocupantes do cargo de ministro do Supremo é a de que a abertura tão grande deles com a imprensa está permitindo que ministros talvez sejam mais próximos de jornalistas do que os próprios colegas de trabalho. Por exemplo, o ministro relata o uso da mídia por alguns ministros do Supremo para fazerem "declarações em off". E, entre eles, afirma ser possível saber aquele que o fez pelo teor das declarações ou pelo estilo da escrita. Mas afirma também que na época em que compôs o Supremo, essas "declarações em off" não eram costumeiramente divulgadass, apesar de existir algumas situações deste tipo (FONTAINHA; SILVA; NUÑEZ, 2015, p. 118-119).

A relação de maior proximidade de um ministro com jornalistas se comparados com a relação estabelecida com os próprios colegas, pode contribuir à situação descrita pelo ministro Sepúlveda Pertence, reconhecendo uma possível falta de diálogos entre os próprios ministros e, eventualmente, gerando supostos conflitos entre eles. Não se está afirmando aqui que a proximidade entre ministros e jornalistas são os principais causadores da falta de diálogos entre eles, e sim que essa aproximação pode ser considerada também como um dos estímulos à ocorrência de possíveis conflitos. Ou ainda que a referida proximidade torne mais visível os conflitos já existentes entre os próprios ministros, manifestados inclusive em sessão plenária.

De todo modo, uma questão surge a partir da discussão entre as relações estabelecidas entre ministros e imprensa, mídia e opinião pública: a relação estabelecida entre os próprios ministros. A partir da intensificação da proximidade aqui descrita, tornam-se mais corriqueiros e visíveis alguns embates envolvendo ministros do Supremo principalmente quando relacionados a casos que, em sua própria visão, possuam uma maior repercussão pública. Para compreender como essas relações entre os próprios ministros são estabelecidas, a partir da visão que imprimem às entrevistas concedidas ao projeto HOSTF, faz-se necessário analisar os trechos em que fazem referência ao assunto, o que será mais bem discutido no tópico seguinte.

\section{TERCEIRA DIMENSÃO: ADMINISTRANDO CONFLITOS NA INFORMALIDADE}

No presente tópico, serão demonstrados alguns trechos de entrevistas em que os ministros do Supremo fazem referência direta ao relacionamento que possuem com outros ministros. A partir da leitura dos depoimentos orais, foi possível perceber que os ministros separam essas relações em diferentes níveis: o relacionamento que possuíam com outros ministros antes mesmo da sua tomada de posse; as relações estabelecidas depois se tornar um ministro do Supremo, dentro e fora do tribunal e, por fim, o relacionamento existente após a aposentadoria. Mais uma vez, os trechos 
colacionados a seguir representarão uma síntese das ideias apresentadas pelos ministros nas entrevistas concedidas, como forma de ilustrar melhor os fatos aqui descritos.

A parte destinada ao destaque das relações estabelecidas entre os ministros demonstrará que, apesar do clima de cordialidade que rege as relações, elas são também conflituosas. Não há nenhum destaque dado pelos ministros ao porquê da existência desses conflitos, embora alguns deles tentam atribuir alguma motivação para a sua ocorrência a fim de tentar compreendê-la. No entanto, os ministros fazem muitas referências às situações criadas para conter os conflitos que surgem no seio das relações por eles estabelecidas. Uma das medidas criadas para conter os conflitos que pudessem inclusive transparecer nas sessões de julgamento era a chamada "sessão de conselho", também chamada por eles de "sessão secreta", "sessão informal", "sessão às portas fechadas". Nessa sessão, os ministros se reuniam antes mesmo da ocorrência do julgamento para discutirem, e até mesmo deliberar acerca de questões que considerassem relevantes, por diversos motivos, como melhor administrar possíveis divergências e conflitos que pudessem ocorrer nas sessões públicas de julgamento, aos quais veremos alguns deles mais adiante.

Deste modo, o presente tópico servirá para demonstrar a relação conflituosa que ministros relatam terem vivido dentro do Supremo, apesar do aparente clima de cordialidade, e o surgimento de medidas que pudessem melhor administrá-las, evitando que eles prejudicassem quaisquer procedimentos, ritos e dinâmicas ocorridas principalmente em plenário. Toda a discussão aqui mencionada terá o seu início já no próximo tópico, em que serão destacadas como as relações são estabelecidas entre os ministros do Supremo para, no tópico seguinte, demonstrar um meio institucionalmente criado para melhorar o diálogo e diminuir possíveis conflitos entre os ministros a partir das relações por eles mesmos estabelecidas.

\section{Falta de convívio ou conflito: o que sustenta as relações entre os ministros?}

Cordialidade. Essa é a palavra eleita pelos próprios ministros para descrever as relações estabelecidas entre eles mesmos. No entanto, não é incomum nos depararmos com notícias da imprensa, comentários em redes sociais acerca de embates, discussões ásperas em plenário, principalmente quando diante da análise de um caso que esteja sendo transmitido ao vivo pela TV Justiça. $O$ que pode causar, na visão de alguns ministros, conforme veremos a seguir, a falsa impressão de que esses embates tenham se intensificado nos últimos anos. Para alguns ministros, os atritos entre ministros do Supremo é uma constante no tribunal, a TV Justiça teria apenas facilitado o reconhecimento de sua existência. De todo modo, a forma como os ministros do Supremo se relacionam despertou curiosidade tanto na comunidade acadêmica como na profissional ${ }^{7} \mathrm{e}$, por mais que se especulem acerca do modo de convivência dentro e fora do tribunal, faltavam declarações próprias a seu respeito. As linhas a seguir

7 Referência feita àqueles que exercem profissões tradicionais no Direito, como juízes, advogados, promotores, defensores públicos, dentre outros. 
tentarão suprir esse déficit, demonstrando, nas palavras dos próprios ministros, como é ou era o convívio entre seus pares.

Ao contrário do que alguns poderiam imaginar, o relacionamento entre os ministros do Supremo é iniciado inclusive antes da tomada de posse de alguns. Tanto o círculo na comunidade acadêmica como a relação estabelecida entre advogados, representantes do Ministério Público e magistrados, ou ainda entre magistrados e membros de algum dos Poderes da República, faz com que, ao tomar posse no cargo de ministro, as relações já existentes tornem facilitada a recepção e o convívio com o ministro recém-chegado. Alguns ministros, por exemplo, relatam a existência do convívio com alguns ministros do Supremo antes mesmo de tomarem posse no cargo. O ministro Eros Grau (FONTAINHA; MAFEI; ACCA, 2016, p. 73-74; p. 81-83) destaca que, antes de tomar posse, já estabelecia relações com alguns ministros do Supremo, porque alguns deles se frequentavam, conviviam fora do tribunal, o que teria se intensificado após a sua tomada de posse. Outro ministro que destaca ter estabelecido relações pessoais com os outros ministros antes de assumir o cargo no Supremo é o Luís Roberto Barroso (FONTAINHA; VANNUCCHI; DOS SANTOS, 2016, p. 104-106), que afirma já ter despachado com vários ministros na condição de advogado, além de ter participado de eventos acadêmicos com alguns deles e até mesmo estabelecer uma relação de amizade com o ministro Luiz Fux desde a época de aprovação deste para o concurso de juiz de primeiro grau.

As relações pessoais e o convívio entre os ministros são intensificados após a tomada de posse e a frequência ao mesmo ambiente de trabalho que, apesar de disponibilizar um gabinete para cada ministro organizar autonomamente a sua força de trabalho, estabelece reuniões periódicas em sessões de julgamento nas turmas e plenário para discutirem e deliberarem acerca de casos que lhes são demandados. Além disso, uma vez assumido o cargo de ministro do Supremo, é aberta a possibilidade de moradia em um apartamento funcional localizado em uma quadra ao final da Asa Sul, em Brasília, onde diversos ministros do Supremo moram e convivem como vizinhos. Ou seja, tanto o convívio constante no trabalho quanto a proximidade de moradia são considerados elementos capazes de estimular o estabelecimento de relações entre os ministros do Supremo fora do ambiente de trabalho.

Apesar do convívio, nos depoimentos orais concedidos, os ministros do Supremo afirmam que, em regra, não existe relação de amizade entre eles. E esse parece ser um pensamento comum entre os ministros, considerando as diferentes épocas que cada um dos entrevistados exerceram o cargo. Na entrevista concedida pelo ministro Célio Borja, por exemplo, o ministro afirma que apesar de ter morado em um mesmo prédio com vários outros ministros do Supremo, ainda assim não existia uma relação mais próxima, afetuosa entre eles (FONTAINHA; DA SILVA; GUIMARÃES, 2015, p. 77).

Apesar de os ministros se frequentarem fora do ambiente de trabalho, nos depoimentos orais, essa não era considerada uma postura comum; diferente de outros tribunais aos quais alguns ministros fizeram parte antes de assumir o cargo no Supremo. Em entrevista concedida pelo ministro Sydney Sanches, quando perguntado sobre o relacionamento com os demais ministros, o ministro afirma que um dos possíveis motivos a essa falta de proximidade entre ele e seus colegas está relacionado às diferentes origens de cada um. Segundo o próprio ministro, essa falta de

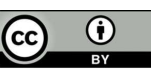

5 JOURNAL OF INSTITUTIONAL STUDIES 1 (2019)

Revista Estudos Institucionais, v. 5, n. 1, p. 171-216, jan./abr. 2019 
proximidade resultava em um isolamento capaz de não se permitir a discussão de matérias jurídicas ou votos, antes da realização da sessão de julgamento, diferente do que ocorria em outros tribunais de justiça existentes no país em que se realizavam seminários para discutir teses jurídicas (FONTAINHA; MATTOS; SATO, 2015, p. 160162).

Em relação à diferença de convivência entre os ministros do Supremo e os magistrados de outros tribunais, fazendo referência ainda que indiretamente à observação feita pelo ministro Sydney Sanches em relação às diferentes origens dos ministros do Supremo, o ministro Cezar Peluso destaca que, no Tribunal de Justiça do Estado de São Paulo, onde foi magistrado, os seus colegas se frequentavam, as famílias eram amigas e até chegavam a marcar viagens juntas, o que não ocorre no Supremo:

[FF] - Ministro, e no TJ era completamente diferente?

[CP] - Completamente diferente! Um ambiente descontraído. Nossa, imagina, a gente se frequentava, casas de amigos em conjunto, saíamos em férias juntos, íamos para Santa Catarina, Itapema, alugávamos 20 chalés, iam 20 famílias de juízes, se reuniam todos, levava filho, neto, todos juntos lá. Associação se reúne, tem festa, vão, falam.

[FF] - E por lá o senhor fez amigos, não fez desafetos, no Supremo foi ao contrário ou não chegou a ser ao contrário?

[CP] - Não, não, não fiz desafetos. Eu pelo menos, pessoalmente, não acho que tenha feito nenhum desafeto. Provavelmente, como ninguém é obrigado a gostar de todo mundo, nem todos me apreciem do mesmo modo, no mesmo nível, mas do meu ponto de vista pessoal não tenho nenhum desafeto, não tenho nada contra nenhum deles do ponto de vista pessoal, nada, nada, nada. As coisas que eu considerava que podiam não ter acontecido, aconteceram, não dei muito relevo, mas não passei disso. Uma pessoa mais próxima dentro do Supremo com quem me relaciono é com o ministro Sepúlveda Pertence. Primeiro, porque eu tenho um grande respeito intelectual por ele - eu o chamo de Zé Paulo - uma das maiores cabeças que passaram pelo Supremo. $\mathrm{Eu}$ o acho uma pessoa extraordinária, eu tenho muita afinidade intelectual com ele, temos posições comuns (...). (FONTAINHA; DA SILVA; DE ALMEIDA, 2016, p. 112-113)

A partir do trecho destacado na entrevista do ministro Cezar Peluso, um traço capaz de aproximar ministros do STF não era em si a convivência fora do tribunal ou a aproximação das famílias, mas uma "afinidade intelectual". Apesar da inexistência de intimidade e proximidade entre as famílias, alguns ministros se frequentavam principalmente quando da organização de jantares. Ainda assim, quando feita referência à organização de tais jantares, o ministro Nelson Jobim estabeleceu uma distinção entre eles, existindo basicamente dois tipos: aqueles cujo objetivo era tão somente a confraternização e outros em que se convocava para falar de trabalho. Dependendo do jantar, não eram todos os ministros que compareciam, alguns 
apresentavam resistência ao comparecimento principalmente dos jantares organizados tão somente para falar de trabalho (FONTAINHA et al., 2016, p. 273-275).

A resistência de alguns ministros a estabelecerem diálogos sobre assuntos de trabalho fora do ambiente institucional se tornava ainda mais radical quando a questão a ser discutida fazia referência a algum caso prestes ser julgado pelo plenário do Supremo. Todos os ministros entrevistados que fizeram referência à possibilidade de combinação de votos, antecipação de pontos de vista ou assuntos correlatos se colocarou contrários à sua ocorrência. $\mathrm{O}$ ministro Cezar Peluso, ao tratar do tema em sua entrevista, compara a situação com os colegas de colegiado do Tribunal de Justiça de São Paulo, que sempre conversavam quer seja por meio de telefone, jantares, bilhetes, dentre outros modos. Por tais motivos, havia previsibilidade sobre a forma como cada um proferiria seus votos no colegiado, o que evitava discussões entre ministros no plenário (FONTAINHA; DA SILVA; DE ALMEIDA, 2015, p. 106).

Em outras palavras, apesar do clima de cordialidade presente entre os ministros, eles evitavam maiores aproximações principalmente para evitar diálogos a respeito de casos a serem por eles apreciados nas sessões de julgamento. Essa falta de diálogo e aproximação, que também resulta na imprevisibilidade a respeito do posicionamento de cada um dos ministros a respeito de determinado caso, é capaz de estimular discussões mais acaloradas nas sessões de julgamento, momentos que têm se tornado mais visíveis devido as transmissões ao vivo das sessões de julgamento ocorridas no plenário pela TV Justiça. Ou seja, o exercício do principal ofício de um ministro do Supremo, a partir das posturas descritas por alguns ministros, deveria ser reservado às sessões de julgamento, revestindo os atos de institucionalidade. E para que o exercício desse ofício fosse facilitado, com o destaque a um ambiente cortês e de convivência pacífica, alguns ministros do Supremo se referem à existência de algumas regras de conduta, sempre guiadas pelo critério da antiguidade.

Em relação ao tema, o ministro Célio Borja destaca que as relações estabelecidas entre os ministros eram também guiadas a partir da existência das regras de convivência aos quais os ministros deveriam seguir, como o estabelecimento de ordem para entrar no elevador, para se assentar à mesa, dentre outros. Ainda assim com a existência de regras de convivência que estimulavam o clima cortês entre os ministros, o ministro Célio Borja destaca algumas exaltações de seus colegas, como uma no que ele chama de "velho Supremo" em que dois ministros andavam armados e se ameaçavam constantemente, porém, sem nunca terem atirado um no outro e, em sua época de ministro, dois que não se falavam até que finalmente se aproximaram (FONTAINHA; DA SILVA; DE ALMEIDA, 2015, p. 106). Sobre o mesmo assunto, o ministro Luís Roberto Barroso afirma que o modo de deliberação existente no Supremo pode estimular algumas discussões mais ásperas, mas destaca que as relações estabelecidas entre os ministros são mais cordiais do que imaginam (FONTAINHA; VANNUCCHI; DOS SANTOS, 2016, p. 104-106).

As declarações dos ministros Célio Borja e Luís Roberto Barroso a respeito da existência de debates mais acalorados representam duas épocas bastante distintas no Supremo: o primeiro aposentou-se do Supremo dez anos antes da criação da TV Justiça e o segundo, tomou posse no Supremo cerca de doze anos depois. No entanto, as discussões mais ásperas entre os ministros eram comuns às duas épocas, estimulando 
o entendimento de que elas representam um traço característico no tribunal. Ainda assim, o tom, e não a frequência, das discussões surpreendiam alguns ministros que tiveram atuação como magistrado em outros tribunais antes de chegarem ao Supremo. O ministro Aldir Passarinho, em seu depoimento oral, destaca ter presenciado uma discussão em que afirma ter ficado "realmente preocupado" com o que viu, mas logo após a sessão os ministros saíram abraçados, conversando, dando a entender que a discussão havia ficado dentro do plenário, não sendo levada adiante (FONTAINHA; SATO, 2015, p. 81-82). Por outro lado, o ministro Eros Grau revela a existência de um "bate-boca violento" entre ele e o ministro Joaquim Barbosa, quase resultando em agressão (FONTAINHA; MAFEI; ACCA, 2016, p. 70-71), afirmando não ter guardado rancor da situação ao mesmo tempo em que tece elogios ao ministro Joaquim Barbosa, com quem teve boa relação durante os tempos de Supremo.

Outro elemento indicado pelo ministro Nelson Jobim capaz de alimentar a existência de discussões mais ásperas no Supremo é a existência de disputas, brigas pessoais entre os próprios ministros, podendo ter sido ocasionada também pela falta de convívio entre eles:

[CJ] - Nesse caso, a sua relação com a composição do Supremo foi importante. Como é que foi, antes do senhor virar presidente?

[NJ] - Era boa. Era ótima.

$[\mathrm{CJ}]$ - Além desse caso, outros conflitos importantes?

[NJ] - Que eu tenha administrado?

$[\mathrm{CJ}]-\hat{\mathrm{E} .}$

$[\mathrm{NJ}]$ - Ah, sim. Havia, às vezes, havia problemas de disputas, brigas pessoais, né? Aí, eu tentava acalmar um ou outro. Eu nunca briguei com ninguém. Eu sempre tentava resolver os acertos e as confusões. Porque tem determinados personagens que alimentam-se do conflito. Ou seja, eles precisam do conflito para se alimentar (...). (FONTAINHA et al., 2016, p. 215)

No trecho da entrevista concedida pelo ministro Nelson Jobim há o destaque ainda à possibilidade de o conflito ser a base capaz de estimular e sustentar as relações entre os ministros no Supremo, e não o diálogo e cooperação, conforme sugerido por alguns ministros ao fazer referência ao ambiente de convívio em outros tribunais. Ao mesmo tempo em que eram identificados mecanismos de isolamentos entre os ministros, buscava-se quer seja por meio de jantares ou o estabelecimento de residências próximas, criar meios de facilitação desse convívio. Por exemplo, na época em que o ministro Moreira Alves ainda compunha o quadro de ministros do Supremo, até depois de sua aposentaria, ele lembra a criação de meios de integração entre os ministros aposentados e os da ativa para manter e estreitar relações, como o convite para participarem do lanche no intervalo da sessão de julgamento (FONTAINHA; DE PAULA; ALMEIDA, 2015, p. 103-104).

Além dos convites para participação nos lanches ocorridos nos intervalos das sessões de julgamento no plenário, haviam ainda jantares de confraternização para os 
ministros aposentados, chamados de "inativos" pelos próprios ministros (FONTAINHA; SATO, 2015, p. 81-82), apesar da resistência de alguns ministros quanto à sua participação no evento e/ ou organização do mesmo.

Por fim, um dos mecanismos criados institucionalmente para permitir uma aproximação maior entre os ministros e estabelecer um diálogo entre eles a respeito de casos considerados importantes - o que poderia gerar, nas palavras do ministro Luís Roberto Barroso, maior fricção no debate -, foi a chamada pelo ministro Sepúlveda Pertence de reunião informal. De acordo com o ministro, em algumas hipóteses era convocada uma reunião para se discutir "aspectos relevantes" de um "julgamento próximo", mas sem tomada de votos, destacando também que a sua realização recebeu radical oposição do ministro Marco Aurélio e que, por isso, não é mais realizada (FONTAINHA; SILVA; NUÑEZ, 2015, p. 115-117).

As referidas reuniões são mencionadas por diversos ministros que concederam entrevistas, sempre explicando o seu funcionamento, a forma com que era convocada, a participação dos ministros, o argumento de oposição de alguns à sua realização, dentre outras questões que serão mais bem discutidas no tópico seguinte.

O objetivo do presente tópico foi demonstrar o modo com que os ministros enxergavam as próprias relações estabelecidas com seus pares. A partir daí, identificou-se o destaque dado por cada um deles ao isolamento com que convivem. Apesar do destaque e da conotação negativa ao isolamento, inclusive caracterizando o Supremo como "onze ilhas", nas palavras do ministro Sepúlveda Pertence, os ministros não relatam tentativas pessoais de aproximação. As tentativas a que foram dadas destaque por eles, referem-se a mecanismos institucionalmente criados para promover maior proximidade entre os próprios ministros, alguns deles não sendo bem vistos pelos próprios. É possível identificar algumas características comuns aos mecanismos citados pelos ministros: além de buscar o estabelecimento de maior diálogo e proximidade entre eles, buscava também administrar possíveis conflitos que poderiam surgir a partir principalmente do convívio isolado de cada um.

E o mecanismo mais comentado por cada um dos ministros é o da convocação de reuniões informais, realizadas às portas fechadas, diferentemente das sessões de julgamento realizadas nas turmas, que contava com a presença do público que comparecia até o tribunal para presenciá-la, e as televisionadas que ocorriam no plenário da corte. Ou seja, após os próprios ministros identificarem o conflito e o isolamento como empecilhos ao desenvolvimento de algumas das atividades que desempenham no Supremo, eles fazem referência a alguns elementos que buscavam combater esse fato, melhor administrando esses conflitos. Na visão dos ministros, as reuniões às portas fechadas contribuíam no cumprimento desse papel, conforme veremos a seguir.

\section{Como proteger a dignidade dos cargos?}

De acordo com o relatado pelos ministros, e destacado em linhas anteriores, o convívio isolado de cada um deles pode ter estimulado a criação de um momento em que, a partir de uma convocação, os ministros se reuniriam informalmente em local apropriado ao estabelecimento de um diálogo entre eles, para discutirem questões a respeito de casos considerados importantes. Considerado como um dos principais 
mecanismos desenvolvidos para suprir o possível déficit de contato entre os ministros, a convocação das reuniões que recebem o nome de informais, intramuros, sessões de conselho, sessões administrativas, sessão secreta, dentre outras, eram bem vistas pelos ministros que comentam a sua existência, apesar da controvérsia existente a respeito da sua ocorrência após a promulgação da Constituição Federal de 1988, conforme veremos a seguir.

As principais motivações ao apoio dos ministros à existência de "sessões secretas" se referem ao modelo de deliberação existente no país, determinando que discussões e deliberações sejam públicas e, especificamente as sessões plenárias do Supremo Tribunal Federal, transmitidas ao vivo por meio de imprensa institucionalmente criada para este fim. Segundo alguns ministros, uma das principais funções que as sessões secretas eram capazes de cumprir é a de mudar, gerar impacto sobre as dinâmicas ocorridas nas sessões de julgamento no plenário do Supremo. E, nesse aspecto, tornam-se inevitáveis as comparações feitas por ministros do Supremo sobre dois importantes e distintos momentos das sessões de julgamento que tanto participaram: aquela caracterizada por discussões realizadas previamente à sua realização (sessões secretas) e as transmitidas ao vivo pela imprensa institucional do tribunal, não sendo, em regra, precedida de qualquer discussão sobre os casos que ali seriam analisados (FONTAINHA; DE PAULA; ALMEIDA, 2015, p. 81-85).

De acordo com o ministro Moreira Alves, as sessões administrativas cumpriam um papel de diminuir os debates ocorridos em plenário, uma vez que no espaço destinado às suas realizações eram discutidas questões que poderiam ser levadas ao plenário do Supremo, o que não ocorre desde a promulgação da Constituição de 1988, devido a manifestação contrária do ministro Marco Aurélio em se discutir processos fora da sessão de julgamento, tendo o seu principal fundamento no art. 93, IX da Constituição Federal.

A inevitável comparação feita pelo ministro Moreira Alves com as diferentes épocas no Supremo permitiu a afirmação de que as sessões administrativas cumpriam um papel melhor do que a TV Justiça exerce ao transmitir ao vivo as sessões de julgamento, inclusive mudando posturas dos ministros nas próprias sessões ao identificar um prolongamento das discussões, votos mais longos e processos que duram mais de uma sessão para ser apreciado, motivos que considera ser o bastante para a sua posição contrária à TV Justiça.

Apesar do reconhecimento da existência de tais sessões, alguns ministros destacam que critérios, seleção de temas e assuntos seriam levados até às sessões. Havia alguns objetivos bem delimitados, como a tomada de decisões sobre o que decidir em plenário, o que era feita a partir da definição das matérias que envolvesse determinados processos, segundo o ministro Rafael Mayer (FONTAINHA; MATTOS; NUÑEZ, 2015, p. 64-67). Além desse, as sessões secretas poderiam cumprir vários outros papéis conforme o descrito pelos ministros, atribuindo destaque a uma das características capazes de marcar as discussões ocorridas nas sessões de julgamento do Supremo: as discussões mais ásperas, já exaustivamente comentada em tópico anterior. Diante dessa característica, os ministros destacam que uma das principais funções das sessões administrativas era a contenção dos ânimos e diminuição dos atritos nas sessões de julgamento que apreciasse casos de maior repercussão, 
oportunidade em que se convocava uma reunião informal para, nas palavras do ministro Aldir Passarinho (FONTAINHA; SATO, 2015, p. 46-49), trocar ideias sem um caráter de definitividade, apenas para pontuar algumas das questões que poderiam ser suscitadas no debate público.

Entretanto, alguns depoimentos orais apresentam versões diferentes a esse respeito. $\mathrm{O}$ ministro Néri da Silveira, ao fazer referência às sessões de conselho, destaca que existiam sessões fechadas em que os ministros deliberavam a respeito de inquéritos de autoridades, sempre a pedido do Presidente do Tribunal, atribuindo destaque também a figura do Presidente na convocação das referidas sessões (FONTAINHA; DA SILVA; DOS SANTOS, 2015, p. 83-84).

Outro aspecto que merece destaque no depoimento do ministro Néri da Silveira refere-se ao argumento utilizado para justificar a deliberação sobre inquéritos de autoridades em sessões fechadas: a dignidade dos cargos. Esse argumento revela (i) o cuidado em não debater em público um caso que pode ser considerado importante a partir das partes que estiverem envolvidas na demanda, (ii) além de considerar a exposição pública como um problema ao futuro exercício de funções ou cargos das partes envolvidas na demanda. Embora este não seja um tema que mereça maior aprofundamento no presente tópico, que tem por objetivo apenas demonstrar a visão impressa pelos ministros do Supremo acerca de alguns fenômenos sócio-jurídicos, o mesmo argumento pode ser levado em consideração para refletirmos acerca das motivações capazes de sustentar a existência de sessões fechadas e, consequentemente, o fim do debate público pelos próprios ministros: o exercício e dignidade do cargo que possuem, além da já mencionada imparcialidade.

Além das funções já destacadas, o ministro Ilmar Galvão aponta outra no que se refere especificamente ao Relator: quando diante de casos de maior repercussão, o relator do processo poderia convocar uma sessão administrativa para buscar apoio dos colegas em relação a determinadas posturas que poderia adotar em relação ao processo de sua relatoria. E destaca como exemplo a pressão da imprensa sobre ele no "Caso Collor", em que havia sido relator: por ter sua trajetória jurídico-profissional marcadamente no Estado do Acre, a imprensa teria alimentado a ideia de que o ministro não teria condições de relatar um processo importante e aparentemente complexo como o "Caso Collor". Então, o ministro Ilmar Galvão convocou uma sessão administrativa para consultar os colegas acerca de sua aptidão para exercer a relatoria do caso (FONTAINHA; ALMEIDA, 2016, p. 54-55).

Esse último exemplo é encarado pelos ministros entrevistados como em caráter de excepcionalidade, principalmente por ter ocorrido após a promulgação da Constituição Federal de 1988. Antes dela, os ministros entrevistados afirmavam com tranquilidade a existência das sessões aqui discutidas, embora não compartilhassem das mesmas ideias quando perguntados acerca do seu momento de convocação, como eram organizadas, o que apreciavam, dentre outras questões. Mas, alguns depoimentos que merecem destaque neste tocante, referem-se à possibilidade e ocorrência de sessões secretas, convocadas pelos próprios ministros, para decidirem temas que não haviam sequer sido demandados enquanto órgão máximo do Poder Judiciário brasileiro. Por exemplo, o ministro Sydney Sanches narra um evento em que recebeu um telefonema enquanto dormia o convidando a participar de uma reunião

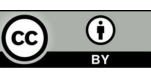


na casa do ministro Moreira Alves para, junto dos demais ministros, decidirem quem assumiria a Presidência da República no lugar de Tancredo Neves: José Sarney ou Ulysses Guimarães. Não há relato de que essa tenha sido uma demanda de alguém, apesar da desconfiança do próprio ministro de que tenha sido do próprio Planalto. Mas, os ministros decidiram tal questão sem uma provocação oficial ao Supremo Tribunal Federal:

$[\mathrm{MM}]$ - E como é que foi ser ministro do Supremo na redemocratização? O Supremo participou disso? Como participou? Como é que o senhor vivenciou, de dentro do Supremo, essa passagem do poder militar para o poder civil?

[SS] - Olha, o... Não houve problema nenhum, viu? Eu vou dar até um depoimento aqui. Quando o... Eu estava dormindo uma noite, e toca o telefone, era o ministro Moreira Alves. Acho que já era uma meia-noite, onze horas ou meia-noite. Ele falou: "Sydney, você não vem aqui?". “Aqui aonde?". “Na minha casa.". “Ué! Ninguém me avisou nada. O que é que está havendo?". "Você não sabe? O Tancredo não vai tomar posse. Ele está sendo operado. E nós temos que resolver quem é que vai tomar posse, se é o Ulysses Guimarães ou se é o Sarney." (FONTAINHA; MATTOS; SATO, 2015, p. 112-114).

Em seguida à transição referida no trecho acima, foi promulgada a Constituição Federal até hoje vigente, que apresentou mudanças significativas em relação ao Poder Judiciário brasileiro. O novo texto constitucional estimulou o debate entre os ministros acerca de diversas questões que lhes afetavam diretamente; dentre elas, a manutenção das sessões secretas - mecanismo que, de acordo com os relatos aqui consultados, contava com a aprovação e apoio de diversos ministros do Supremo. O que gerou certa resistência à Constituição por parte dos ministros que prezavam e defendiam a manutenção das sessões secretas (FONTAINHA; MATTOS; NUÑEZ, 2015, p. 73).

Ao destacar alguns dos efeitos da promulgação da nova Constituição, o ministro Rafael Mayer destaca a necessidade de os julgamentos no Poder Judiciário brasileiro serem públicos, afirmando não mais ter ocorrido as sessões secretas. Além do art. 93, IX, da Constituição vedar a possibilidade de ocorrência de julgamentos a portas fechadas, em diversos depoimentos orais, há referências constantes à oposição do ministro Marco Aurélio quando perguntado aos ministros o principal motivo das sessões secretas não serem mais realizadas, conforme visto em parágrafos anteriores. Apesar da aparente vedação de sua ocorrência pela Constituição Federal de 1988, é possível destacar em diversos relatos dos ministros do Supremo a realização de sessões às portas fechadas, sempre referida como "sessão administrativa", sendo utilizada inclusive como forma de combinar posturas a serem adotadas no curso de uma sessão de julgamento televisionada.

O ministro Sepúlveda Pertence relata que, antes do julgamento do "Caso Collor", ocorreu uma reunião administrativa, para os ministros discutirem possíveis comportamentos a serem tomados na sessão plenária, hipótese em que restou combinado que não existiriam apartes durante a sessão, a fim de se evitar a 
transmissão ao vivo de possíveis atritos surgidos em plenário. A situação destaca uma preocupação dos ministros à época em como a transmissão ao vivo das sessões de julgamento do plenário poderia influenciar as dinâmicas ali ocorridas (FONTAINHA; SILVA; NUÑEZ, 2015, p. 110).

Para a convocação dessas sessões administrativas, havia critérios e as funções que as sessões cumpriam eram próximas às realizadas antes da Constituição de 1988. Por exemplo, ao relatar o modo pelo qual as discussões ocorriam no plenário do Supremo, o ministro Carlos Velloso afirma que em "casos realmente complicados, solicitava-se o chamado por ele de "Conselho": reunião administrativa prevista no regimento interno do tribunal ${ }^{8}$. Segundo o próprio ministro Carlos Velloso, essa reunião administrativa era convocada principalmente em casos de dúvidas dos ministros acerca de como proceder no caso para tomar a sua decisão e também quando não conheciam o ponto de vista do colega, citando como exemplo o caso da constitucionalidade do CNJ. Em hipóteses como as descritas, o ministro solicitava a realização do "Conselho", que ocorria em dia anterior ao julgamento (FONTAINHA; DE PAULA; NUÑEZ, 2015, p. 136-137).

A inexistência reconhecida de diálogo a respeito de casos que serão apreciados e julgados pelo plenário é motivo de desconforto de diversos ministros. No entanto, a discordância não parece ser problema, uma vez que não houve pronunciamentos a seu respeito. Para os ministros, o problema parece ser a imprevisibilidade, e não a discordância. $\mathrm{O}$ ministro Cezar Peluso ao destacar o seu desconforto, afirma inclusive que as discussões em plenário deveriam ocorrer em reunião privada, porque um dos efeitos dessa falta de diálogo previamente às sessões plenárias era o aumento do pedido de vista, o que atrasa o julgamento (FONTAINHA; DA SILVA; DE ALMEIDA, 2015, p. 104-105).

Ao comparar as sessões de julgamento ocorridas no STF com as da Supreme Court dos Estados Unidos, o ministro Cezar Peluso lamenta que no Brasil as deliberações não ocorram em reuniões privadas, afirmando que o formato estimula o debate e não inibe magistrados de proferirem opiniões. No entanto, Peluso alega ser irreversível a mudança para não mais se permitirem a transmissão ao vivo das sessões de julgamento do Supremo devido a reação contrária da sociedade a esse respeito, que argumentaria no sentido de os ministros estarem escondendo as razões de decidir.

Por fim, um personagem a que constantemente é feito referência quando da análise das sessões secretas, que já surgiu em variados momentos nos trechos de entrevistas do presente tópico, é o Presidente do Supremo. É do Presidente do Supremo a competência para convocar e dirigir as sessões secretas do tribunal, de acordo com o relato dos ministros. Apesar de todo o poder manifestado pelo presidente na convocação das sessões, ele possui várias outras formas de manifestação do poder que lhe foi conferido pelo tribunal ao elegê-lo como seu administrador e representante,

\footnotetext{
${ }^{8}$ A disposição está prevista no Regimento Interno do Tribunal desde o primeiro regimento do tribunal datado de 1891: “art. 29. As sessões e votações serão públicas, salvo nos casos excetuados neste Regimento, ou quando no interesse da Justiça ou da moral resolver o presidente, que se discuta e vote em sessão secreta". E, atualmente, a possibilidade de realização das sessões administrativas está prevista nos arts. 151, 152 e 153.
} 
dentre eles o de chamar processos em pauta para julgamento para que os ministros possam apreciá-los.

Mas, de acordo com o depoimento oral dos ministros, nem sempre é assim. Há casos considerados mais importantes em que a inclusão ou retirada de pauta de um processo é discutida em uma sessão secreta. O ministro Nelson Jobim relatou um caso em que negociou diretamente a inclusão e retirada de pauta para julgamento de um processo referente ao vencimento e auxílio-moradia dos magistrados brasileiros, sendo negociada em sessão administrativa. E, uma vez colocado em pauta para julgamento, após o ministro Nelson Jobim ter afirmado já dotar das informações necessárias ao seu julgamento, um dos ministros solicitou a retirada do processo da pauta para julgamento, afirmando que só o faria se permitissem que ele negociasse com o Poder Executivo e tivesse "carta branca" para decidir, alegando que ninguém poderia negociar com o Poder Executivo se não tivesse poder de decisão. Assim, o ministro Nelson Jobim afirmou que a "carta branca" seria a concordância e homologação pelos demais ministros de toda decisão que tomasse no caso (FONTAINHA et al., 2016, p. 210-212).

No exemplo acima é possível notar duas manifestações de poderes: de um lado o presidente do tribunal e, do outro, o relator do processo. No entanto, a figura do relator do processo é mencionada apenas nesse caso para demonstrar a negociação existente para o presidente chamar ou não um caso à votação, uma vez que, após o ministro relator do processo fazer o pedido para incluir ou retirar o processo de pauta para julgamento, é o presidente do tribunal que decide o melhor momento para chamá-lo a julgamento. O caso mencionado pelo ministro Nelson Jobim representa uma estratégia do relator para convencer o presidente do tribunal a homologar suas preferências.

Nesse sentido, a figura do presidente do tribunal passa a ganhar especial relevo dentro deste quadro entendido como "atos preparatórios para as sessões às portas abertas" ao se tornar responsável por administrar e representar o tribunal perante não apenas os que o elegeram, mas todo o Poder Judiciário brasileiro. No tópico seguinte, então, serão destacados trechos de entrevistas que fazem referência ao exercício da Presidência do Supremo, sempre relacionando ao seu impacto no exercício do colegiado às portas abertas, destacando contribuições, influências, interferências diretas e indiretas à realização de uma sessão plenária de julgamento.

\section{QuARTA DiMENSÃO: A GESTÃo do PROCESSO PElo PRESIDENTE}

Personagem constantemente mencionado nas entrevistas até aqui colacionadas, a competência do Presidente do Supremo vem se redesenhando ao longo principalmente dos últimos anos. Com o protagonismo judicial na vida política e social, o órgão máximo do Poder Judicial brasileiro tem alcançado maior visibilidade no cenário nacional, associado sempre a figura de seu presidente, responsável por administrar o tribunal e representar não apenas os ministros que o elegem, mas toda a magistratura nacional, conforme veremos a seguir. O Presidente do Supremo, em tempos de participação constante na vida política e social do tribunal na sociedade brasileira, tem sido o responsável por lhe dar voz perante quaisquer situações em que o órgão seja demandado, além de representar o Poder Judiciário nacional no 
estabelecimento de relações com os demais poderes da República e até mesmo ocupando lugar na ordem de sucessão ao cargo de Presidente da República.

Além de todas as competências já descritas, existem diversas outras funções fundamentais ao Presidente do Supremo, principalmente em relação à organização do plenário. Em texto escrito em co-autoria com Fernando Fontainha, destaco algumas características capazes de atribuir especial atenção a esse personagem:

\begin{abstract}
Além das já mencionadas, novas práticas estão sendo institucionalizadas a partir da prerrogativa que o presidente possui em guardar os procedimentos da corte, como: (i) alterar o sistema de colheita de votos - em casos determinados pelo próprio presidente, primeiro garante-se o livre debate do tema a partir dos apontamentos feitos pelo relator e, apenas se houver divergência, são colhidos os votos dissonantes; (ii) interpretar o quórum para apreciação dos processos em pauta - para apreciar uma ADI, o quórum mínimo é de oito ministros presentes no prédio destinado às sessões de julgamento ou no espaço destinado a manifestarem seus votos?; (iii) administrar conflitos a parir da convocação de intervalo em momentos de acaloradas discussões; (iv) permitir que sustentações orais e manifestações de voto ocorram em sessões de julgamento diferentes, dentre outras posturas. ${ }^{9}$
\end{abstract}

Esse constante redesenho institucional é feito também pelo lado de fora do plenário, não sendo visivelmente notado pelos telespectadores que apenas assistem as sessões de julgamento indo ao plenário ou por intermédio da TV Justiça. Tentando também suprir um déficit em relação a esse aspecto do exercício das funções de presidente do Supremo, o tópico a seguir demonstrará algumas das funções exercidas pelo presidente para não apenas organizar o tribunal, mas principalmente permitir a ocorrência das sessões plenárias ao mesmo tempo em que preserva a imagem do tribunal, liberdade de debates entre os ministros, diminuição de pressões sofridas por eles, a imparcialidade, a dignidade dos cargos...enfim, todos os elementos já mencionados no presente artigo e que os ministros consideram fundamentais à ocorrência das sessões de julgamento às portas abertas e o consequente exercício da colegialidade.

\title{
1. Organizando o plenário pelo lado de fora: o exercício da presidência no Supremo Tribunal Federal
}

Em todos os trechos das entrevistas aqui mencionadas, representativo das entrevistas analisadas em sua completude, não há referências à atuação do Presidente do Supremo nas sessões de julgamento às portas abertas. Todas as menções feitas ao presidente faziam referências às atuações fora do plenário, exemplificadas por

9 Disponível em: <http://jota.info/judiciario-e-sociedade-os-donos-do-plenario>. Acesso em: 03 nov. 2016. 
situações principalmente em que se manifestavam poderes. As ações que objetivavam administrar o tribunal - o que inclui possíveis conflitos de ideias que possam surgir entre os próprios ministros -, são visíveis nos relatos dos ministros entrevistados. Mas não o seriam para apenas aqueles que assistem às sessões de julgamento, por não transparecer essa sua forma específica de atuação. Um dos objetivos do presente tópico é demonstrar, de acordo com o narrado por alguns ministros, como o presidente do tribunal pode agir de modo a organizar o plenário não apenas de acordo com os ritos judiciários, mas também a partir de suas próprias preferências.

Nesse sentido, serão reconstruídas aqui algumas das competências e posturas dos ministros do Supremo a partir dos depoimentos orais concedidos ao projeto HOSTF. Ou seja, o objetivo não é esgotar cada uma das suas funções, mas ressaltar as que, para os próprios ministros, podem influenciar e estabelecer relações diretas ou indiretas com o passo seguinte à fixação da pauta de julgamento: o chamamento de um processo para manifestação de posicionamento e colheita de votos por parte de cada um dos ministros que compõem a corte. Assim, será demonstrado o empenho do presidente do tribunal à realização daquele considerado um dos principais ritos judiciários no Supremo Tribunal Federal: o exercício do colegiado.

Uma das principais funções a ser exercidas por um Presidente do Supremo é a de administrar o tribunal, adotando as medidas necessárias para melhor geri-lo, o que inclui dirigir os trabalhos e presidir as sessões plenárias, zelar pela ordem e disciplina no tribunal, convocar audiência pública, representar o tribunal perante os demais poderes, dentre outras funções descritas dos arts. 12 a 14 do atual Regimento Interno do tribunal. Nos últimos anos, a partir do já mencionado protagonismo judicial na vida do cidadão, os trabalhos exercidos pelo presidente perante o tribunal tornaram-se ainda mais visíveis, sendo amplamente divulgados pela imprensa e lembrados até com satisfação pelos próprios ministros presidentes.

Por exemplo, durante o exercício da Presidência do Supremo, o ministro Néri da Silveira afirma ter trabalhado em prol da informatização do tribunal, desde a distribuição dos processos até a publicação dos acórdãos apreciados e julgados pelo Supremo. Ainda no exercício da presidência, o ministro afirma ter organizado vários encontros com presidentes de todos os tribunais do país para organizar a magistratura nacional e implementar nacionalmente o sistema informatizado nos tribunais, além da materialização do alcance da autonomia administrativa e financeira dos Tribunais de Justiça (FONTAINHA; DA SILVA; DOS SANTOS, 2015, p. 98-101). A informatização do sistema de Justiça também foi uma das preocupações do ministro Carlos Velloso enquanto ocupou o cargo de Presidente do Supremo (FONTAINHA; DE PAULA; NUÑEZ, 2015, p. 156-159).

Outra competência do Presidente do Supremo é o de chamar processos que estão em pauta de julgamento para serem apreciados e julgados pelos demais ministros do Supremo nas sessões de julgamento às portas abertas. No entanto, quem pede a inclusão ou retirada de processo nas pautas para julgamento são os ministros relatores que, após identificarem no processo todos os elementos necessários ao seu julgamento, solicitam ao Presidente do Tribunal que o processo seja incluído na pauta de julgamento (FONTAINHA; DA SILVA; DOS SANTOS, 2015, p. 111-112). 
Ocorre que diversos processos são incluídos e retirados da pauta de julgamento diariamente, o que não garante que todos os processos inclusos em pauta sejam imediatamente chamados para julgamento pelo ministro presidente. Isto é, após a inclusão de um processo na pauta de julgamento, o ministro presidente possui liberdade de escolha para decidir quais processos serão chamados para julgamento e em que sessões. O referido poder pode ser manifestado de diferentes formas, vejamos algumas: inclusão estratégica de processo para julgamento após perceber um quórum qualificado de ministros para apreciar determinada demanda; aguardar que mais fatos relacionados ao processo ocorram para que ele seja apreciado; acelerar ou retardar julgamentos a partir de possíveis consequências oriundas de tomadas de decisões; retardar processos aguardando uma mudança de composição da corte ou construção de uma maioria, dentre outras questões.

Em resumo, o chamamento de processos em pauta para julgamento representa um dos mais visíveis poderes manifestados pelo Presidente do Supremo. E tentando modificar algumas das consequências do exercício desse poder, o ministro Nelson Jobim afirma ter criado a chamada pauta temática que, segundo o próprio, teria acelerado julgamentos, aumentado o estudo prévio de ministros acerca dos processos e questões discutidas nas sessões de julgamento e, consequentemente, diminuído os pedidos de vista (FONTAINHA et al., 2016, p. 216-218).

Para o ministro Nelson Jobim, essa era uma forma de diluição de poderes, o que foi bem visto por permitir uma maior preparação dos ministros para enfrentamento de questões complexas nas sessões de julgamento, além de representar uma forma de aproximação maior dos ministros com o presidente do tribunal. Demonstrando essa maior aproximação do Presidente com os ministros do Supremo, Nelson Jobim destaca também que quando diante de um "assunto difícil", procedia a "conversas individuais" com seus pares, a fim de buscar solidariedade no pleito que estava buscando. Apenas após a construção da maioria que o ministro procedia à realização de reuniões, apenas para aprovar o que já havia sido antes negociado. Como exemplo do evento descrito, o ministro Nelson Jobim cita a negociação feita para aprovar os indicadores de custo, valor, dentre outros, criados enquanto Presidente do Conselho Nacional de Justiça (FONTAINHA et al., 2016, p. 223-224).

A postura de busca pelo estabelecimento de um diálogo parece ser uma das que agradam os próprios ministros do Supremo, que além de destacar o seu lado positivo, nos depoimentos orais concedidos afirmam que é também de competência do ministro presidente administrar os conflitos existentes no tribunal por meio de uma maior aproximação e, sobretudo, do estabelecimento de diálogos. Essa é uma postura que ministros do Supremo prezam que faça parte inclusive dos próximos presidentes do Tribunal. Em entrevista concedida pelo ministro Luiz Fux, há o destaque de algumas posturas que deveriam ser comuns aos Presidentes do Supremo, como construir diálogos e diminuir os conflitos gerados tanto pelo isolamento dos ministros quanto dos estimulados pela imprensa (FONTAINHA; VANNUCCHI; NUÑEZ, 2016, p. 9192).

O exercício do cargo de Presidente do Supremo é um dos momentos que encerra o ciclo descrito pelos ministros que foram entrevistados considerados como atos ou fatos que antecedem a sessão de julgamento, como identificar o quórum mínimo de abertura

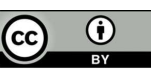

5 JOURNAL OF INSTITUTIONAL STUDIES 1 (2019)

Revista Estudos Institucionais, v. 5, n. 1, p. 171-216, jan./abr. 2019 
da sessão, fixar pauta dos julgamentos que serão chamados para serem apreciados e preservar os ritos judiciários utilizados como organizadores do espaço institucionalmente criado para ministros discutirem e deliberarem a respeito de casos e questões que sejam demandados.

Nesse tópico, foram destacadas posturas, perfis de um Presidente do Supremo, além de formas em que é exigido a manifestar seus poderes. Ao mesmo tempo em que pode manifestar com liberdade os poderes que possui, alguns ministros entendem que diluir seus próprios poderes podem ser considerados medidas hábeis ao estabelecimento de um diálogo e construção da confiança, elementos considerados importantes pelos próprios entrevistados para o exercício do cargo de Presidente do Supremo. No próximo tópico, será apresentado um mapeamento de fases e categorias que melhor ilustrariam todos os momentos até aqui descritos. E, uma vez que parece encerrado o percurso necessário à chegada das sessões de julgamento às portas abertas, é também coerente compreender o modo como ministros entrevistados enxergam os eventos ocorridos nas sessões de julgamento às portas abertas (DOS SANTOS, 2017).

\section{ORGANIZANDO CATEGORIAS NARRATIVAS E MAPEANDO O DISSENSO: TRAÇANDO PERCURSOS ATÉ A SESSÃO DE JULGAMENTO}

A pesquisa até aqui desenvolvida apresenta uma peculiaridade: a inclusão de trechos de entrevistas que, somados, podem gerar algum desconforto em relação tanto à sua quantidade quanto ao espaço que cada uma delas ocupa no texto. No entanto, a opção em manter essa estrutura se justifica em dois importantes aspectos. O primeiro deles refere-se à utilização de uma fonte primária de pesquisa. A opção em colacionar os trechos de entrevistas, além de considerações a seu respeito acrescidas de remissões ao local de onde foi extraída, representa a demonstração do modo como os sujeitos da pesquisa estruturam o seu discurso; lembrando que foi feita uma seleção de trechos representativos dos momentos a que os ministros estavam fazendo referência em seus depoimentos orais.

O outro aspecto refere-se ao modo como os entrevistados estruturam o raciocínio utilizando-se de categorias narrativas. E um dos objetivos do presente artigo é também demonstrar que categorias são utilizadas pelos sujeitos da pesquisa para fazer referência a fenômenos sócio-jurídicos capazes de sintetizarem situações e, sobretudo, ampliar o poder explicativo acerca de determinados atos ou fatos. Assim, os trechos das entrevistas aqui colacionados justificam-se também na necessidade de explicitar que categorias são utilizadas pelos entrevistados para descrever, rotular, explicar momentos que podem apresentar alguma significação à construção do raciocínio aqui iniciado: identificar um dos percursos possíveis para que o ministro conduza um processo até alguma das sessões de julgamento no tribunal. 
Nos tópicos anteriores, além de organizar visões dos entrevistados acerca de determinados momentos, buscou-se estabelecer conexões entre esses momentos, a partir principalmente do explicitado nos depoimentos orais dos ministros entrevistados. E por meio da leitura dos referidos trechos, foi possível identificar que categorias são utilizadas para fazer referência aos momentos que os entrevistados descrevem. Após a identificação das categorias, elas foram organizadas de modo a representar momentos e dispostas em sequência a fim de destacar algumas possíveis fases de um percurso cujo destino é a composição e participação de uma sessão de julgamento.

O resultado foi a criação do que se aproxima do chamado mapa conceitual $^{10}$ (TAVARES, 2007, p. 74; AUSUBEL, 2003, p. 166), mas se distinguindo dele por se tratar da composição e demonstração de categorias narrativas e, portanto, representar uma análise empírica do discurso. De forma bem resumida, o "mapa" está disposto em momentos, chamados aqui de dimensões, destacando não se tratar de fatos descritos de forma sequencial. Sendo assim, as categorias "principais" (capazes de sintetizar ou rotular momentos) estão dispostas em letra maior e em negrito, estabelecendo conexões por meio de uma linha sólida. As categorias manifestadas pelos entrevistados estão em letras menores, sem o negrito e conectadas por uma linha tracejada representam ideias ou conceitos subsidiários surgidos a partir da explicitação dos conceitos principais. O objetivo é tão somente organizar o conteúdo do que até aqui foi exposto, conforme será visto a seguir:

Figura 1 - Mapeamento da produção de uma decisão judicial no supremo

\footnotetext{
10 Segundo Tavares (2007, p. 72), “é uma estrutura esquemática para representar um conjunto de conceitos imersos numa rede de proposições. Ele é considerado como um estruturador do conhecimento, na medida em que permite mostrar como o conhecimento sobre determinado assunto está organizado na estrutura cognitiva de seu autor, que assim pode visualizar e analisar a sua profundidade e a extensão. Ele pode ser entendido como uma representação visual utilizada para partilhar significados, pois explicita como o autor entende as relações entre os conceitos enunciados."
} 


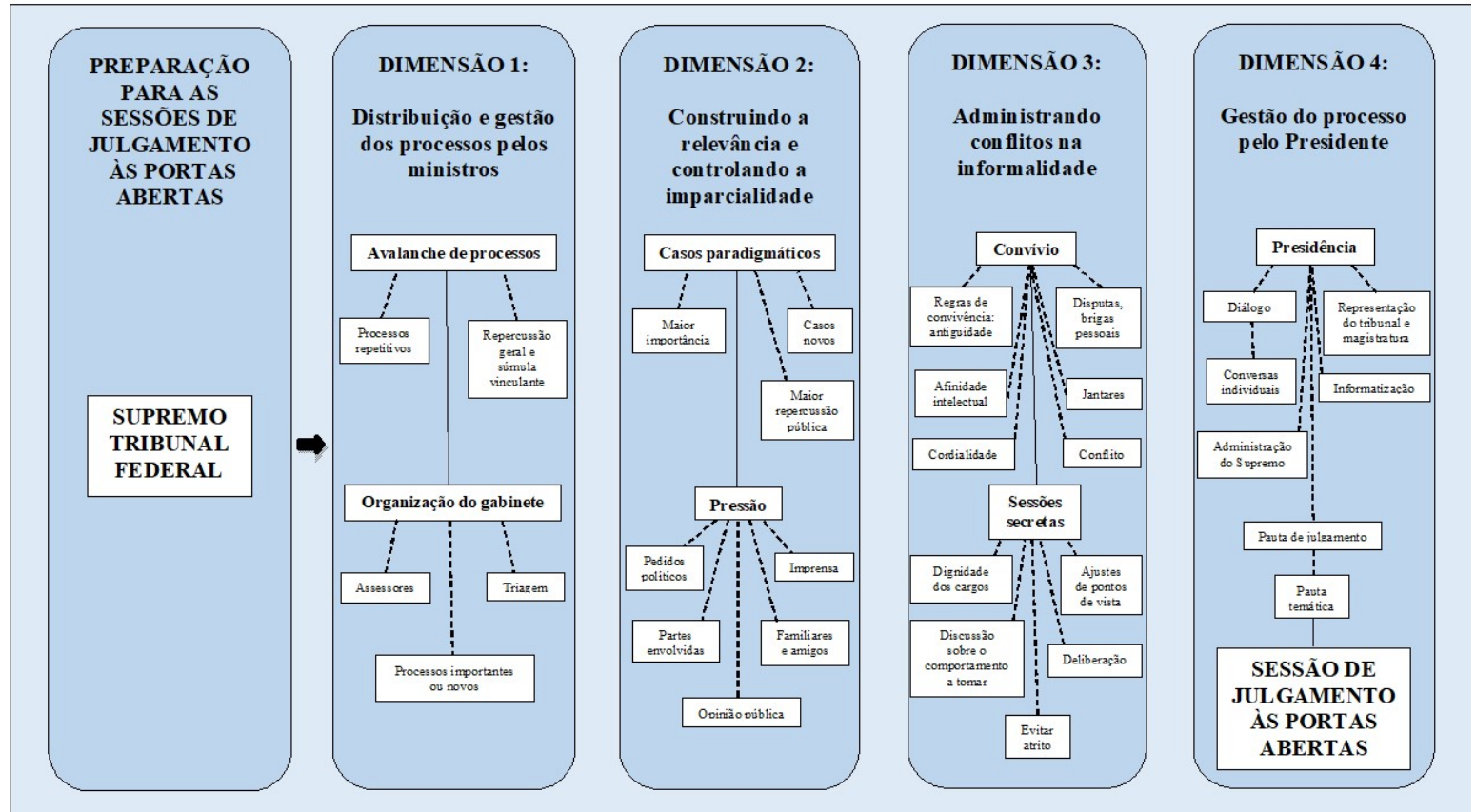

Fonte: elaborado pelo autor.

Conforme foi possível notar, a preparação para a composição e participação de uma sessão de julgamento às portas abertas apresenta algumas particularidades. Um dos possíveis caminhos que permita a sua compreensão refere-se ao momento em que o ministro se depara com uma quantidade não esperada de processos em seu gabinete, dentre os herdados de seu antecessor, passando pelos pedidos de vista, até os que lhes são distribuídos diariamente, e identifica a necessidade de organizar ali a sua força de trabalho. Momento diverso refere-se à possibilidade de criação de mecanismos para lidar com as pressões que sofrem para apreciar casos considerados importantes. Alguns ministros associam o aumento das pressões recebidas nos julgamentos desses casos importantes à aproximação maior do tribunal e seus membros da mídia, imprensa e opinião pública, o que, por outro lado, ressalta e torna mais clara a inexistência de proximidade entre os ministros do Supremo. Apesar da cordialidade com que se tratam, a inexistência de proximidade entre os ministros acaba resultando na criação de disputas, brigas pessoais e, consequentemente, conflito. O que pode contribuir para que não discutam sobre trabalho (o que inclui pontos de vista, votos, dentre outros) fora do ambiente institucionalmente criado para tanto: as sessões de julgamento às portas abertas. Para melhor administrar os conflitos existentes, diversos mecanismos são criados, quase sempre na informalidade (considerada aqui principalmente como aspectos não institucionais), como a discussão sobre casos específicos em sessões secretas, isto é, às portas fechadas. Nesse contexto, surge um personagem a que os ministros fazem constantemente referência quando diante de situações que façam ressaltar a existência de conflitos: o presidente do tribunal que, 
além de convocar e presidir as sessões secretas, tem a competência para chamar processos em pauta para julgamento para apreciação do colegiado.

Os percursos acima parecem destacar caminhos possíveis à chegada na sessão de julgamento às portas abertas, o que não significa que não existam outros. Os caminhos aqui descritos representam apenas os que os ministros atribuíram maior destaque em suas entrevistas, atentando para o dado que, pelo esforço empenhado, esses podem ser reconhecidos como alguns dos percursos que os entrevistados gostariam que fossem notados. De todo modo, eles são representativos de formas específicas de organização de saberes não antes relatados ou observados, capazes de destacar eventos que podem exercer influências sobre alguns fenômenos sócio-jurídicos de interesse da presente pesquisa.

\section{CONSIDERAÇÕES FINAIS: O QUE AS ENTREVISTAS ANALISADAS PODERIAM NOS REVELAR?}

Em um primeiro momento, a pesquisa aqui produzida se utilizou de fontes criadas pelos depoimentos orais dos ministros entrevistados no curso do projeto HOSTF para demonstrar como ministros fazem referência e enxergam procedimentos, dinâmicas necessariamente produzidas para o alcance das sessões de julgamento ocorridas a portas abertas. A partir dos destaques por eles atribuídos, buscou-se estabelecer caminhos a serem percorridos até as sessões de julgamento, desde a chegada de um processo nos gabinetes até o chamamento desse mesmo processo pelo Presidente da Corte para sua apreciação e julgamento pelos demais ministros.

No curso desse processo, foi inevitável a identificação de algumas diferentes dimensões que permitam compreender como um processo chega à sessão de julgamento, sendo organizados da seguinte forma: Dimensão 1 - Distribuição e gestão dos processos pelos ministros; Dimensão 2 - Construindo a relevância e controlando a imparcialidade; Dimensão 3 - Administrando conflitos na informalidade; e Dimensão 4 - Gestão do processo pelo Presidente. Na chamada primeira dimensão, foram abordadas duas vertentes: uma do ministro recém-chegado se deparando com a quantidade de processos com que teria que lidar diariamente em sua nova função; e outra a respeito da chegada constante de processos no gabinete, hipótese em que o ministro seria estimulado a agir como gestor, buscando criar meios para melhor gerir a sua força de trabalho juntamente das atividades a serem desempenhadas. Uma das atividades/posturas dos ministros que auxiliam nesse processo é a triagem dos processos, momento em que se identifica quais processos são considerados importantes e quais representam demandas já passadas e repetidas. E é no curso dessa atividade que os ministros identificam as chamadas pressões por julgamento.

A segunda dimensão identificada revela a relação estabelecida entre ministros e a mídia, imprensa e opinião como uma medição de forças. Se por um lado, os ministros revelam sofrer diferentes pressões por mais celeridade na apreciação de determinadas demandas e até mesmo por tomadas de certas decisões; por outro, os ministros buscam desenvolver meios e práticas capazes de preservar a sua imparcialidade e, consequentemente, a legitimidade do exercício da profissão que possuem. No entanto, o estabelecimento de uma relação de proximidade com a mídia, imprensa e opinião 
pública tornou mais clara uma situação bastante comentada pelos ministros em seus depoimentos pessoais: o convívio isolado dos ministros do Supremo, quer seja no ambiente de trabalho ou fora dele. O que demonstra a inexistência de diálogos, laços de amizade ou quaisquer outros meios capazes de facilitar o convívio e impactar nas dinâmicas de trabalho que possuem, como: conversarem sobre casos, trocarem votos ou discutirem posicionamentos antes da ocorrência da sessão de julgamento.

A situação acima evidenciada permite o ingresso na terceira dimensão do mapeamento aqui produzido: a identificação de isolamentos, falta de diálogos e a necessidade de administração dos conflitos delas proveniente. Nessa fase, foi demonstrado o estabelecimento de uma associação feita por parte dos ministros entre o convívio isolado e o surgimento de alguns conflitos, o que ocorre em diferentes épocas no Supremo. E uma das medidas criadas institucionalmente para melhor gerir esses conflitos foi a chamada por alguns de "sessões secretas", ou melhor, sessões a portas fechadas. Essa medida era adotada quando diante de casos de grande repercussão ou de aparente complexidade e era convocada para diferentes fins: desde combinar determinadas posturas nas sessões a portas abertas até deliberarem a respeito de determinadas demandas. E o personagem que ganha destaque principalmente nesse momento é o Presidente do Supremo, responsável por convocar, organizar e presidir as ditas sessões.

O Presidente do Supremo, então, surge como um dos administradores do conflito, exercendo sua função por meio da manifestação de poderes que possui ao assumir o cargo representativo não apenas de seus colegas julgadores no Supremo, mas de toda a magistratura nacional. Assim, é dado início à última dimensão, chamada de "gestão do processo pelo Presidente", oportunidade em que são apresentadas algumas das funções exercidas pelo Presidente do Supremo antes da ocorrência das sessões às portas abertas e que podem impactar direta ou indiretamente nas dinâmicas ali ocorridas. Nessa fase, uma das mais comentadas manifestações de poderes pelos ministros entrevistados refere-se à pauta de julgamento, momento em que o ministro presidente, a partir dos processos ali inseridos, seleciona quais serão chamados a julgamento pelos ministros que compõem a corte, entendido como um dos últimos atos ou fatos ocorridos, relatados nas entrevistas, antes da abertura da sessão de julgamento a portas abertas.

Muito embora as questões aqui trazidas reflitam práticas, incluindo variadas descrições de ações apresentadas pelos próprios sujeitos da pesquisa, as ações aqui descritas não foram identificadas a partir da observação e interação com os atores. A presente pesquisa apresenta algumas práticas identificadas no discurso desses atores, cujo objetivo sequer era o de descrevê-las, mas apresentar narrativas a respeito da história institucional do Supremo a partir de seu envolvimento com a instituição. E a partir da identificação de diversos trechos de entrevistas em que os atores faziam menção à existência de práticas que antecediam a realização das sessões de julgamento a portas abertas, buscou-se agrupar tais referências atribuindo-lhes sentidos capazes de destacar possíveis ações responsáveis também por preparar a realização dessas sessões. O que nos remete também a noção de "bastidores" (backstage) apresentada por Goffman (1975) ao fazer referência às relações regionais, podendo ser compreendidas 
como aquelas que ocorrem em "qualquer lugar que seja limitado de algum modo por barreiras à percepção" (Goffman, 1975, p. 101).

Goffman (1975) distingue três tipos de regiões que coexistem: a região de fachada, a região dos bastidores (também chamada de região de fundo) e a região do exterior. O presente artigo é capaz de demonstrar a região dos bastidores - entendida como aquela onde, afastadas dos olhos da plateia, ocorrem práticas cujo objetivo é a preparação da prestação do serviço, ou nas palavras do autor, a preparação da execução da representação (1975, p. 102). A representação a que faço menção refere-se à metáfora teatral de Goffman, em que cada pessoa representa um "eu" para cada interação por ela estabelecida. O que permite que, em cada interação socialmente estabelecida, a pessoa, ao mesmo tempo representa um "eu", também esconde outro, cujo objetivo seria não distorcer ou embaraçar seu propósito caso o mesmo fosse revelado. Para Goffman (1975, p. 67):

O indivíduo influencia o modo que os outros o verão pelas suas ações. Por vezes, agirá de forma teatral para dar uma determinada impressão para obter dos observadores respostas que lhe interesse, mas outras vezes poderá também estar atuando sem ter consciência disto. Muitas vezes não será ele que moldará seu comportamento, e sim seu grupo social ou tradição na qual pertença.

E na região dos bastidores, os ministros podem imprimir ritmos próprios e específicos de trabalho a ponto de se descontrair e, sobretudo, abster-se de representar e sair do personagem que teria que representar na sessão de julgamento às portas abertas. É possível citar como exemplo o jogo realizado pelo ministro Luiz Fux com seus assessores dentro do gabinete em que afirma que ganharia aquele que apresentasse o melhor argumento e o convencesse (FONTAINHA; VANNUCCHI; NUÑEZ, 2016, p. 115-117). Situação diversa a ocorrida na sessão de julgamento, podendo ser entendida como aquela em que o ministro apresenta maior vigilância em sua representação.

Segundo Goffman, a região dos bastidores é capaz de representar uma passagem à chamada região da fachada, local onde a representação é executada. Na presente pesquisa, a região da fachada deve ser entendida como a sessão de julgamento a portas abertas, local onde as interações que interessam à presente pesquisa acontecem. Isto é, enquanto nos bastidores é possível identificar uma dimensão organizacional, na região da fachada as atividades são orientadas principalmente à comunicação face a face. E, devido à dificuldade em se realizar pesquisa que tornasse possível observar e descrever as ações identificadas nos depoimentos orais dos ministros entrevistados e aqui transcritas optou-se por organizá-las de modo a oferecer noções acerca das variadas dimensões que o processo de preparação dos ministros à atuação em uma sessão de julgamento a portas abertas pode ter.

Todos os caminhos aqui percorridos não têm por objetivo revelar momentos ou fases seguidas até a suposta apreciação e julgamento de um processo, mas organizar o modo como os ministros do Supremo transparecem suas ideias para registrar a forma como desejam que as práticas aqui destacadas sejam notadas. Nesse sentido, o

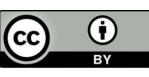


presente artigo é capaz de destacar diferentes modos que os atores que reivindicam exercer a colegialidade gostariam que ela fosse compreendida.

Assim, o presente texto representa apenas algumas dimensões do percurso até à chegada de um processo às sessões de julgamentos a portas abertas, mas já se torna suficiente para atribuir reflexões ao seguinte problema de pesquisa: "como os juízes decidem?". O artigo apresenta diversas situações que, além de não serem levadas em consideração na busca de resposta ao problema de pesquisa formulado, somente são observáveis e vividas pelos próprios atores e sujeitos da pesquisa: os ministros do Supremo (e sua equipe de trabalho em determinadas situações). O que demonstra tornar complicada a atribuição de resposta ao problema de pesquisa aqui transcrito. Na literatura, sobretudo jurídica, existem diversos autores clássicos e contemporâneos que buscam responder a indagação a partir de análise jurisprudencial ou aplicação de sofisticadas teorias que buscam aumentar o poder explicativo dos comportamentos dos magistrados. No entanto, elas não são capazes de alcançar diversos momentos aqui narrados pelos próprios ministros, tornando ainda mais difícil o alcance de respostas à indagação aqui reproduzida.

Diante das reflexões aqui apresentadas, surge a necessidade de reformulação do problema de pesquisa aqui transcrito e investigado por um grande número de professores e pesquisadores. Isso porque, o modo como as decisões são construídas podem não refletir como os juízes decidem. As perguntas podem ainda não estar refletindo as investigações conduzidas por quem o encara como um problema de pesquisa, considerando que a indagação aqui lembrada se aproxima de uma análise de fundamentação das decisões, o que difere do problema de pesquisa proposto. Diante do contexto aqui descrito, mais importante do que responder perguntas e "resolver" problemas de pesquisa é a escolha adequada, refletida, das perguntas que conduzirão os atos na pesquisa.

E o proposto por este artigo não é apenas uma reformulação desses problemas de pesquisa, mas a compreensão do que cada material ou método utilizado para pesquisa possa nos oferecer. E o potencial revelado pela pesquisa ora apresentada é o de atribuir destaque a uma forma peculiar a respeito do modo como os atores de pesquisa gostariam de ser vistos e lembrados, fazendo registros que se tornaram fontes históricas de pesquisa a respeito de uma instituição judiciária a partir de seu próprio protagonismo.

\section{REFERÊNCIAS}

ALBERTI, V. Manual de história oral. 2. ed. revista e atualizada. Rio de Janeiro: Editora FGV, 2004.

ARGUELHES, Diego Werneck; e RIBEIRO, Leandro Molhano. As indicações presidenciais para o Supremo Tribunal Federal e seus fins políticos: uma resposta a Mariana Prado e Cláudia Turner. Revista de Direito Administrativo. Rio de Janeiro, v. 255, p. 115-143, set./dez. 2010. 
AUSUBEL, D.P. Aquisição e Retenção de Conhecimentos: Uma Perspectiva

Cognitiva. Lisboa: Plátano Edições Técnicas, 2003.

DA SILVA, Virgílio Afonso. Deciding without deliberating. International Journal of Constitutional Law, v. 11, p. 557-584, 2013.

FONTAINHA, Fernando de Castro; MATTOS, Marco Aurélio Vannucchi Leme de; NUÑEZ, Izabel Saenger. História Oral do Supremo [1988-2013], v. 1: Rafael Mayer. Rio de Janeiro: Editora FGV, 2015.

FONTAINHA, Fernando de Castro; SATO, Leonardo Seiichi Sasada. História Oral do Supremo [1988-2013], v. 2: Aldir Passarinho. Rio de Janeiro: Editora FGV, 2015.

FONTAINHA, Fernando de Castro; SILVA, Angela Moreira Domingues; NUÑEZ, Izabel Saenger. História oral do Supremo [1988-2013], v. 3: Sepúlveda Pertence. Rio de Janeiro: Editora FGV, 2015.

FONTAINHA, Fernando de Castro; DA SILVA, Angela Moreira Domingues; DE ALMEIDA, Fabio Ferraz. História oral do Supremo [1988-2013], v. 4: Cezar Peluso. Rio de Janeiro: Editora FGV, 2015.

FONTAINHA, Fernando de Castro; MATTOS, Marco Aurélio Vannucchi Lemos de; e SATO, Leonardo Seiichi Sasada. História oral do Supremo [1988-2013], v. 5: Sidney Sanches. Rio de Janeiro: Editora FGV, 2015.

FONTAINHA, Fernando de Castro; DA SILVA, Angela Moreira Domingues; GUIMARÃES, Fabrícia. História oral do Supremo [1988-2013], v.6: Célio Borja. Rio de Janeiro: Editora FGV, 2015.

FONTAINHA, Fernando de Castro; DE PAULA, Christiane Jalles; NUÑEZ, Izabel Saenger. História oral do Supremo [1988-2013], v.7: Carlos Velloso. Rio de Janeiro: Editora FGV, 2015.

FONTAINHA, Fernando de Castro; DA SILVA, Angela Moreira Domingues da; e DOS SANTOS, Carlos Victor Nascimento. História oral do Supremo [1988-2013], v.8: Néri da Silveira. Rio de Janeiro: Editora FGV, 2015. 
FONTAINHA, Fernando de Castro; DE PAULA, Christiane Jalles; GUIMARÃES, Fabrícia; SATO, Leonardo Seiichi Sasada. História oral do Supremo [1988-2013], v. 09: Nelson Jobim. Rio de Janeiro: Editora FGV, 2016.

FONTAINHA, Fernando de Castro; MAFEI, Rafael; ACCA, Thiago dos Santos. História oral do Supremo (1988-2013), v.10: Eros Grau. Rio de Janeiro: Editora FGV, 2016.

FONTAINHA, Fernando de Castro; VANNUCCHI, Marco Aurélio; DOS SANTOS, Carlos Victor Nascimento. História oral do Supremo [1988-2013], v.11: Luis Roberto Barroso. Rio de Janeiro: Editora FGV, 2016.

FONTAINHA, Fernando de Castro; VANNUCCHI, Marco Aurélio; NUÑEZ, Izabel Saenger. História oral do Supremo [1988-2013], v.12: Luiz Fux. Rio de Janeiro:

Editora FGV, 2016.

FONTAINHA, Fernando de Castro; DE PAULA, Christiane Jalles; ALMEIDA, Fábio Ferraz. História oral do Supremo [1988-2013], v.13: Moreira Alves. Rio de Janeiro: Escola de Direito do Rio de Janeiro da Fundação Getúlio Vargas, 2015.

FONTAINHA, Fernando de Castro; e ALMEIDA, Fábio Ferraz. História oral do Supremo [1988-2013], v.14: Ilmar Galvão. Rio de Janeiro: Escola de Direito do Rio de Janeiro da Fundação Getúlio Vargas, 2016.

FONTAINHA, Fernando de Castro; MAFEI, Rafael. História oral do Supremo [19882013], v.15: Francisco Rezek. Rio de Janeiro: Editora FGV, 2016.

GOFFMAN, Erving. A representação do eu na vida cotidiana. Editora Vozes: Rio de Janeiro, 1975.

LEWANDOWSKI, Andressa. O Direito em última instância. Tese de doutorado apresentada ao Programa de Pós-graduação em Antropologia Social da Universidade de Brasília para obtenção do título de Doutor em Antropologia, 2015. 
MENDES, Conrado Hübner. Constitutional Courts and Deliberative Democracy. 1. ed. Oxford: Oxford University Press, 2013.

OLIVEIRA, Fabiana Luci de. Processo decisório no Supremo Tribunal

Federal: coalizões e "panelinhas". Rev. Sociol. Polit., v. 20, n. 44, p. 139-153, 2012.

PRADO, Mariana; TURNER, Claudia. A democracia e o seu impacto nas nomeações dos diretores das agências reguladoras e ministros do STF. Revista de Direito Administrativo, 2009.

DOS SANTOS, Carlos Victor Nascimento dos. A colegialidade nos tribunais: quando uma ideologia vira dogma e o dogma um princípio. Revista de Estudos Institucionais, v. 3, n. 1, 2017.

SILVA, Jeferson Mariano. Jurisdição constitucional em Espanha (1981-1992) e Brasil (1988-1997). Tese de doutorado apresentada ao Programa de Pós Graduação em Ciência Política do IESP-UERJ, 2016, 401p.

TAVARES, Romero. Construindo mapas conceituais. Ciências \& Cognição, v. 12: 7285, 2007. Disponível em: <http://www.cienciasecognicao.org/>. Acesso em 06 nov. 2016.

VALE, André Rufino do. Argumentação Constitucional: um estudo sobre a deliberação nos Tribunais Constitucionais. Tese de doutorado apresentada ao Programa de Pós graduação em Direito, Universidade de Brasília, 2015, 416p. 